$\begin{array}{lll}\text { Makalenin Türü / Article Type } & : \text { Araştırma Makalesi / Researh Article } \\ \text { Geliş Tarihi / Date Received } & : 21.03 .2019 \\ \text { Kabul Tarihi / Date Accepted } & : 02.06 .2020 \\ \text { Yayın Tarihi / Date Published } & : 15.09 .2020 \\ \text { doi) https://dx.doi.org/10.17240/aibuefd.2020..-542763 } & \underline{2}\end{array}$

\title{
SON YİRMİ YILDA TÜRKIYY'DE SOSYAL BİLGİLER ÖĞRETMENLİĞİ LİSANS PROGRAMLARI
}

\author{
Deniz TONGA ${ }^{1}$
}

ÖZ

Bu çalışmanın amacı, son yirmi yılda üç kez güncellenen sosyal bilgiler öğretmenliği lisans programını çeşitli açılardan değerlendirmektir. Araştırma nitel araştırma yaklaşımına uygun olarak tasarlanmış ve veri toplama aracı olarak doküman incelemesi kullanılmıştır. 1998, 2006 ve 2018 Sosyal Bilgiler Öğretmenliği Lisans Programları üzerinden betimsel analizlere yer verilmiştir. Elde edilen bulgular ışığında, 1998 Programı'nda yan alan uygulaması ile Türkçe derslerinin fazlalığı dikkat çekmektedir. 2006 Programı, sosyal bilgileri oluşturan sosyal bilim disiplinlerinin çoğuna yer vermesi ile dikkat çekerken, 2018 Programı'nda bu yaklaşımdan vazgeçilmiş ve dersler ağırlıklı olarak meslek bilgisi (eğitim bilimleri) içerikli derslerden tercih edilmiştir. Teori ve uygulama açısından bakıldığında 1998 Programı'nda 32 saat olan uygulamalı dersler, 2006 Programı'nda 28 saate, 2018 Programı'ndaysa 14 saate düşmüştür. 1998 Programı'nda seçmeli derslerin sayısı 3 iken, 2018 Programı'nda seçmeli derslerin sayısı 16'ya yükselmiştir. En dikkat çekici bulgulardan birisiyse programlarda ders sayısının artmasına karşın ders saatlerinin azalmasıdır. 1998 Programı'nda yer alan ders sayısı 57 ve saat karşılığı 163 iken, 2018 Programı'nda ders sayısı 68, saat karşılığı ise 154'tür. Zaman içinde programlarda bazı derslerin isimlerinin değiştiği, bazı derslerin ise 2018 Programı'nda yer almadığı, ulaşılan sonuçlar arasındadır.

Anahtar Kelimeler: Sosyal bilgiler, sosyal bilgiler öğretmenliği lisans programı, sosyal bilimler.

\section{SOCIAL STUDIES EDUCATION UNDERGRADUATE PROGRAMS IN TURKEY OVER THE LAST TWENTY YEARS}

\begin{abstract}
This study aims to evaluate the social studies teaching undergraduate program which has been updated three times in the last two decades. The research was designed in accordance with the qualitative research approach and document analysis was used as a data collection tool. Descriptive analyses are given through 1998, 2006, 2018 programs of social studies education. In the light of the findings obtained, it is noteworthy in 1998 program, with the side-field application; the number of Turkish courses is remarkable. While the program of 2006 attracted attention with many social science disciplines forming social studies, this approach was abandoned in the 2018 program and the courses were mainly preferred from courses with professional knowledge (educational sciences). From the theoretical and practical point of view, the practical courses which were 32 hours in the 1998 program decreased to 28 hours in the 2006 program and 14 hours in the 2018 program; while the number of elective courses was 3 in the 1998 program, the number of elective courses increased to 16 in the 2018 program. One of the most striking findings is the decrease in the hours of courses in the programs despite the increase in the number of courses. The number of courses in the 1998 program is 57 and 163 course hours, whereas the number of lessons is 68 in the 2018 program and 154 in the hour. In time, it was concluded that the names of some courses changed and some courses were not included in 2018 program.
\end{abstract}

Keywords: Social studies, social studies undergraduate program, social science.

\footnotetext{
${ }^{1}$ Kırlkkale Üniversitesi, Eğitim Fakültesi, deniztonga@hotmail.com @ $\underline{\text { https://orcid.org/0000-0002-8367-8778 }}$
} 


\section{GíRiş}

Sosyal bilgiler eğitiminin tarihi sadece bir yüzyıllık geçmişe sahiptir. Amerika'da XX. yüzyılın başından itibaren artan göç, ekonomik şartlar ve sıkıntılar, ırkçılık gibi sorunlar karşısında yeni yetişen çocuklara yardımcı olmak amacı yönündeki gayretler sosyal bilgiler dersini ortaya çıkarmıştır (İnan, 2014). Çocukları hayata hazırlamaya yardımcı olabilmek için okul programlarında yer alan sosyal bilgiler dersi çok yönlü ve disiplinler arası bir yapıya sahiptir. Her ülkenin kendi koşullarına ve eğitim anlayışına bağlı olarak değişik içeriklere sahip olsa da sosyal bilgiler dersinin içeriğini sosyal bilimler oluşturur. Sosyal bilgiler dersi Türkiye'de 1968 yllından itibaren okul programlarında yer almıştır (Aslan, 2016). Sosyal bilgiler, insan yaşamının önemli bir parçası olan toplumsal boyutun gerektirdiği bilgileri, değişik bilim dallarından yararlanmak suretiyle birleştirerek, etkin, üretken, demokratik ve çağa uygun vatandaşlar yetiştirmek amacıyla oluşturulmuş bir derstir (Kaymakcı \& Ata, 2012). Günümüzde sosyal bilgiler dersi ilkokul dördüncü sınıfta ve ortaokul beșinci, altıncı ve yedinci sınıflarda üçer saat olmak üzere müfredatlarda yer almaktadır. Sosyal bilgiler dersinin en temel amacı, etkili vatandaş yetiştirmeye katkı sağlamaktır. Etkili vatandaşılı ise bireyin topluma etkin olarak katılması, haklarını öğrenmesi, kullanması ve toplumun bir parçası hâline gelmesi ile ilgilidir.

Sosyal bilgiler, sosyal bilimler alanında elde edilen bilimsel bilgileri öğrencilerin seviyelerini de dikkate alarak kullanır. Böyle bir tanım doğrultusunda sosyal bilgiler dersine, sosyal bilimlerin pedagojik ilkeler çerçevesinde öğrenciler için basitleştirilmiş bir hâlidir denebilir (Evans, 2004; Kabapınar, 2014). Sosyal bilgiler dersinin içeriğini oluşturan sosyal bilimlere tarih, coğrafya, ekonomi, sosyoloji, psikoloji, hukuk, felsefe, siyaset bilimi, arkeoloji ve antropoloji örnek olarak verilebilir. 2017 yllında yürürlüğge giren yeni sosyal bilgiler programında derse ilişkin yeni bir tanım yapılmamıştır. 2005 Programı'nda ise sosyal bilgiler şu şekilde tanımlanmıştır: Bireyin toplumsal varoluşunu gerçekleştirebilmesine yardımcı olması amacıyla, tarih, coğrafya, ekonomi, sosyoloji, antropoloji, psikoloji, felsefe, siyaset bilimi ve hukuk gibi sosyal bilimlerin ve yurttaşlık bilgisi konularının, öğrenme alanlarını yansıtan bir ünite ya da tema altında birleştirilmesini içeren, insanın sosyal ve fiziki çevre ile etkileşiminin geçmiş, bugün ve gelecek bağlamında incelendiği toplu öğretim anlayışından hareketle oluşturulmuş bir ilköğretim dersidir (MEB, 2005).

Sosyal bilgiler ile ilgili tanımların ortak noktalarını incelediğimizde şu noktalar ortaya çıkmaktadır:

1- Sosyal bilgilerin temel amacı vatandaşlık eğitimidir.

2- Vatandaşlık eğitimi dört önemli ve zorunlu boyutu kapsamaktadır. Bunlar bilgi, bilgi işleme becerileri, demokratik değer ve inançlar ve sosyal katılım becerileridir.

3- Sosyal bilgilerin bilgi temelini sosyal bilimler ve insanla ilgili tüm bilgiler oluşturmaktadır. Bu bilgiler insanların tarihsel boyutta diğer insanlarla ve çevreleriyle etkileşimlerinin bilgisidir (Doğanay, 2008). Tay (2011) ise literatürde sosyal bilgiler ile ilgili geçen tanımlardaki temel unsurları, etkili vatandaş yetiştirme, kültürleme, çocuğa görelilik, bilgi temeli, yöntem, zaman (geçmiş, bugün, gelecek), alan ve ders boyutu şeklinde ifade etmiştir.

Sosyal bilgiler dersinin vatandaşlık eğitimi ile beraber öğrencilere sağladığ katkılara şunlar örnek olarak gösterilebilir:

Kendini gerçekleştirme: Sosyal bilgiler her bireyin gelişmesini bilgi, beceri ve değerle besler. Yani bireyin kendini tanımasına imkânlar sunar.

İnsan ilişkileri: Öğrenciler, milletlerin kültürel çeşitliliğgi hakkında bilgi edinir, kişiler arası iletişim becerisini geliştirir ve gruplar arası problemleri analiz eder.

Vatandaşlıkla ilgili sorumluluk: Sosyal bilgiler okul içinde ve dışında vatandaşlık katılımının, karar verme becerisinin ve bireylerin yasal haklarının önemini vurgular.

Ekonomi Yeterliliği: Öğrencilerin kaliteli iş, kariyer farkındalıkları ve kaynakların kullanımı ile ilgili kavramları, tutumları ve becerileri keşfetmesine yardım eder.

Düşünme Becerisi: Öğrenme aktiviteleri öğrencilerin karar verme, problem çözme, yaratıcı düşünme, eleştirel düşünme becerilerini kapsar.

Nasıl Öğreneceğini Öğrenme: Öğrenciler bağımsız çalışma etkinliklerine katılırlar. Bu etkinliklerde öğrenme ve yazma becerilerini kullanırlar ve kendi çalışmalarını nasıl yönlendireceklerini ve değerlendireceklerini öğrenirler (Garcia \& Michaelis, 2001, 13’ten akt. Tonga, 2013).

Demokratik bir toplumda sosyal bilgiler öğretiminin temel amacı, bireylerde karar verme, yorumlama, problem çözme ve öneride bulunma gibi önemli becerileri geliştirmektir. Bilgiyi elde eden birey, sonrasında yaşamına taşıyarak kullanabilmeli, değerlerini inceleyip tutum ve davranışlarını uygun şekilde geliştirmeli ve etkin vatandaş olarak toplumsal yaşam problemlerinin çözümünde yer alabilmelidir (Akbaba \& Aksoy, 2019). 
Yukarıda değinildiği üzere insan ve toplum yaşamı için çok önemli değerlere ulaşmayı amaçlayan sosyal bilgiler dersi için bu amaçların gerçeklemesine katkı sağlayacak öğretmenler de büyük önem taşımaktadır. Ortaokullara sosyal bilgiler öğretmeni yetiştirmek amacıyla sosyal bilgiler öğretmenliği lisans programları 1998 yılında öğrenci almaya bașlamıștır. Sosyal bilgiler öğretmenliği bölümü ilk mezunlarını 2002 yılında vermiștir (YÖK, 2007). Sosyal bilgiler eğitimi müfredatları ile sosyal bilgiler öğretmenliği lisans programlarında yapılan güncelleme çalışmaları peş peşe olacak şekilde gerçekleşmiştir. Zira 2005 yılında yeni bir yaklaşımla ülkemizde okutulmaya başlayan sosyal bilgiler dersinin hemen ardından 2006 yılında yeni sosyal bilgiler öğretmenliğgi lisans programı yürürlüğe girmiş̧ir. Yine 2017 yılında sosyal bilgiler müfredatında değişikliğin olmasının hemen ardından 2018 yılında yeni sosyal bilgiler öğretmenliği lisans programı uygulanmaya başlamıştır.

İlgili literatür incelendiğinde sosyal bilgiler lisans eğitimine ilişkin, öğretmen adaylarının sosyal bilgiler öğretmenliği lisans programına ilişkin görüşlerini içeren çalışmalar (Akhan, 2015; Karasu Avcı, 2017; Şahin \& Güvercin Çetinoğlu, 2006; Tonga, 2016; Ünlü vd., 2015; Yılmaz, 2009), sosyal bilgiler öğretmenliği lisans programlarını değerlendirmeyi amaçlayan çalışmalar (Özav, 2001; Tonga, 2012) ve farklı yıllarda yapılan, sosyal bilgiler öğretmenliği lisans programlarını çeşitli açılardan karşılaştıran çalışmalar bulunmaktadır (Kaymakçı, 2012; Sağdıç, 2018). Bu ve benzeri çalışmalar ile iki program kıyaslanmış veya öğretmen adaylarının, öğretmenlerin programa ilişkin görüşleri tasvir edilmiştir. Ulaşılabildiği kadarıyla 1998, 2006 ve 2018 Sosyal Bilgiler Öğretmenliği Lisans Programlarını bir arada değerlendiren ve teorik-uygulamalı derslerin dağılımı, sosyal bilimlerin dağılımı, meslek bilgisi, alan eğitimi ve genel kültür seçmeli derslerinin dağılımı gibi çeşitli açılardan karşılaştıran bir çalışmaya rastlanılmamıştır. Oysa bir eğitim programının başlangıcı ile son geldiği noktayı çeşitli açılardan değerlendirmek önem taşır. Başlangıç ile günümüzde olan değişiklikler ve bunların nedenlerini anlamak, hâlihazırda kullanılan programı anlamak açısından önemlidir. Dolayısıyla bu çalışma ile sosyal bilgiler öğretmenliğinin son yirmi yılına ışık tutmak, programlarda meydana gelen değişimi ortaya koymak, programları birbirleri ile kıyaslamak amaçlanmıştır. Böylece literatürde var olduğuna inanılan bir boşluk da doldurulmaya çalışılacaktır. Bu bağlamda araştırmada başlangıçtan günümüze sosyal bilgiler öğretmenliği lisans programında meydana gelen değişiklikleri ortaya koymanın, ileride yapılacak lisans programı değerlendirme çalışmaları için kaynaklık edeceği düşünülmektedir. Bu çalışmada aşağıdaki sorulara cevap aranmıştır:

1- 1998, 2006 ve 2018 Sosyal Bilgiler Öğretmenliği Lisans Programlarında yarıyıllara göre derslerin dağılımı nasıldır?

2- 1998,2006 ve 2018 Sosyal Bilgiler Öğretmenliği Lisans Programlarında teorik ve uygulamalı derslerin dağılımı nasıldır?

3- 1998, 2006 ve 2018 Sosyal Bilgiler Öğretmenliği Lisans Programlarında seçmeli derslerin dağılımı nasildır?

4- 1998, 2006 ve 2018 Sosyal Bilgiler Öğretmenliği Lisans Programlarında sosyal bilimler disiplinlerinin dağılımı nasıldır?

5- 1998, 2006 ve 2018 Sosyal Bilgiler Öğretmenliği Lisans Programlarında meslek bilgisi, genel kültür ve alan eğitimi derslerinin dağılımı nasıldır?

\section{YÖNTEM}

\subsection{Araştırmanın modeli}

"Sosyal bilgiler öğretmenliği lisans programında son 20 yılda yaşanan değişim nasıldır?" sorusuna cevap arandığ 1 için bu araştırma nitel araştırma yaklaşımına uygun olarak tasarlanmıştır. Nitel araştırmayı, gözlem, görüşme ve doküman analizi gibi nitel bilgi toplama yöntemlerinin kullanıldığı, algıların ve olayların doğal ortamda gerçekçi ve bütüncül bir biçimde ortaya konmasına yönelik nitel bir sürecin izlendiği araştırma olarak tanımlamak mümkündür (Yıldırım, 1999).

\subsection{Verilerin toplanması}

Veri toplama aracı olarak, problem cümlesi hakkında en etkili veriyi toplayacağına inanılan doküman incelemesi kullanılmıştır. Doküman incelemesi, araştırılması hedeflenen olgu veya olgular hakkında bilgi içeren yazılı belgelerin analizini kapsar (Yıldırım \& Şimşek, 2008). İncelenen dokümanlar 1998, 2006 ve 2018 Sosyal Bilgiler Öğretmenliği Lisans Programları ile sınırlı tutulmuş ve sadece Yüksek Öğretim Kurumu'nun belgeleri esas alınmıştır. Verilere 2019 yılında ulaşılmıştır. Programlara ilişkin belgelerin bir kısmı Yüksek Öğretim Kurumu'nun resmi internet sitesinden, bir bölümü ise yine Yüksek Öğretim Kurumu'nun basılı eserlerinden temin edilmiştir. İncelenen belgelere ilişkin internet erişim adresleri, baskı bilgileri ve detaylara aşağıda yer verilmiştir.

1- Eğitim Fakültesi Öğretmen Yetiştirme Lisans Programları - 1998 
http://www.yok.gov.tr/documents/10279/30217/Egitim_fakultesi_ogretmen_yetistirme_lisans_programl ari_mart_98.pdf/5e166018-b806-48d5-ae13-6afd5dac511c

2- Eğitim Fakültesi Öğretmen Yetiştirme Lisans Programları - 2007 http://www.yok.gov.tr/documents/10279/30217/E\%C4\%9E\%C4\%B0T\%C4\%B0M+FAK\%C3\%9CLT ES\%C4\%B0\%20\%C3\%96\%C4\%9ERETMEN+YET\%C4\%B0\%C5\%9ET\%C4\%B0RME+L\%C4\%B0 SANS+PROGRAMLARI.pdf/054dfc9e-a753-42e6-a8ad-674180d6e382

3- Öğretmen Yetiştirme Lisans Programları (2018 - Ankara Üniversitesi Basımevi Müdürlüğü) Sosyal Bilgiler Lisans Programı ile ilgili bölümler için internet erişim adresleri: http://www.yok.gov.tr/documents/10279/41805112/Sosyal_Bilgileri_Ogretmenligi_Lisans_Programi.p df http://www.yok.gov.tr/documents/10279/41805112/AA_Sunus_+Onsoz_Uygulama_Yonergesi.pdf

\subsection{Verilerin analizi}

Elde edilen veriler üzerinden betimsel analizlere yer verilmiştir. Betimsel analizde elde edilen veriler daha önceden belirlenen temalara göre özetlenir ve yorumlanır. Betimsel analiz; betimsel analiz için bir çerçeve oluşturma, tematik çerçeveye göre verilerin işlenmesi, bulguların tanımlanması ve bulguların yorumlanması şeklinde dört basamaktan meydana gelmektedir (Yıldırım \& Şimşek, 2008).

Verilerin analizi aşamasında eğitim programları ve öğretim anabilim dalında çalışan ve aynı zamanda sosyal bilgiler eğitimi ile ilgili yayınları olan iki akademisyenden ve sosyal bilgiler eğitiminde çalışan üç akademisyenden uzman görüşü alınmış, bulgular bu akademisyenlerle tartış1lmış ve analizlere son şekli verilmiştir.

\section{BULGULAR}

\subsection{Birinci araştırma sorusu ile ilgili bulgular}

“1998, 2006 ve 2018 Sosyal Bilgiler Öğretmenliği Lisans Programlarında yarıyıllara göre derslerin dağılımı nasıldır?” alt probleme ilişkin elde edilen veriler aşağıda yarıyıllara göre tablolarda sunulmuştur.

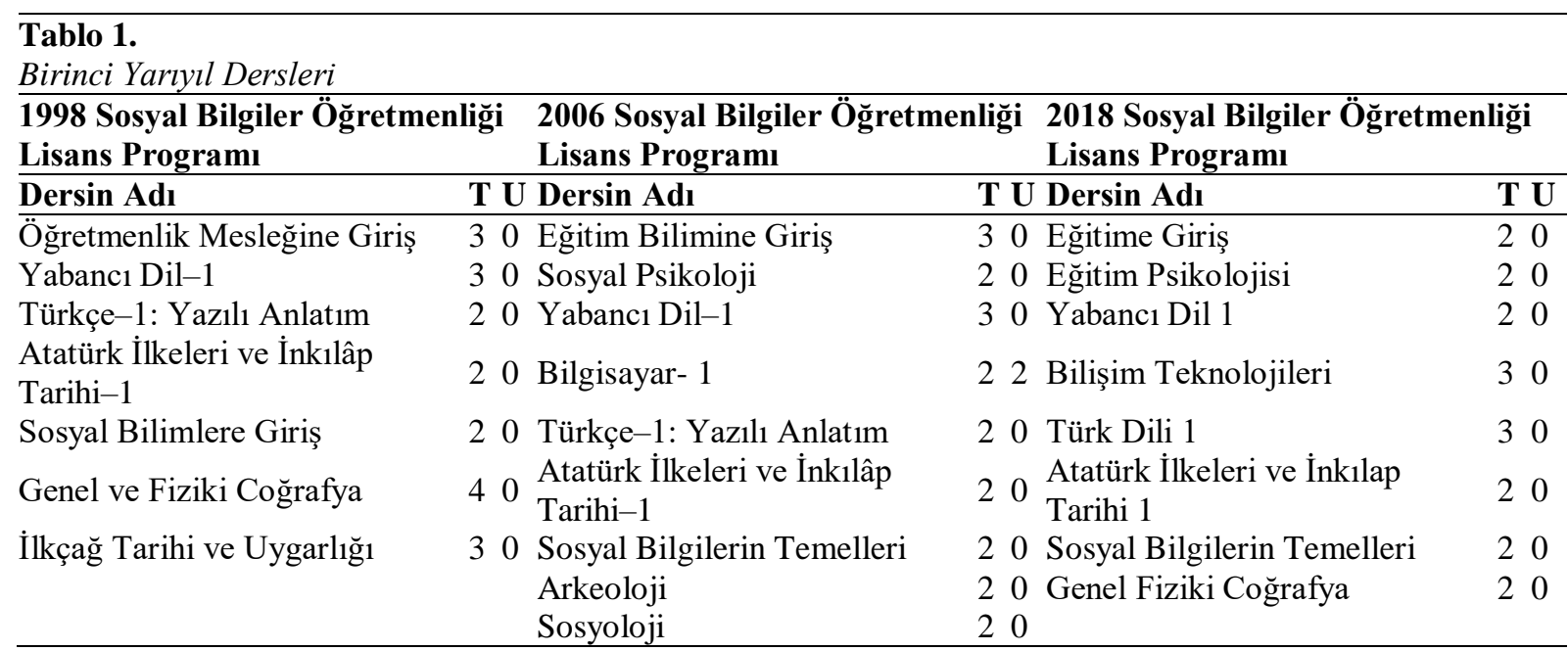

Tablo 1'de yer alan derslere baktığımızda 1998 Programı'nda 7, 2006 Programı'nda 9, 2018 Programı'nda ise 8 dersin olduğu görülmektedir. Yabancı Dil 1 ve Atatürk İlkeleri ve İnkılap Tarihi 1 dersleri üç programda da vardır. 1998 yılında Sosyal Bilimlere Giriş adı altında okutulan dersin yerini diğer yıllarda Sosyal Bilgilerin Temelleri dersi almıştır. 1998 ve 2006 yıllarında Türkçe 1 Yazılı Anlatım olan ders ise bir ders saati artırılarak 2018 yılında Türk Dili 1 olarak programda kendine yer bulmuştur. 1998 yılında Öğretmenlik Mesleğine Giriş dersi 2006 yılında Eğitim Bilimine Giriş, 2018 Programı’nda ise Eğitime Giriş dersi olarak karşımıza çıkmaktadır. 2006 yılında Bilgisayar 1 olarak okutulan ders 2018 yılında Bilişim Teknolojileri olarak değişmiştir. Genel ve Fiziki Coğrafya dersi 1998 ve 2018 yılları programında yer alırken, Arkeoloji ve Sosyoloji dersi 2006 Programı'nda yer almıştır. Sosyal Psikoloji 2018 yılı programı içinde yer almayıp, daha önceden 2006 Programı'nda dördüncü yarıyıl dersi olarak okutulan Eğitim Psikolojisi dersi 2018 yılı programında birinci dönem dersi olmuştur. İlkçağ Tarihi ve Uygarlığı dersi sadece 1998 yılı programında bulunmaktadır. 2006 yılında Bilgisayar 1 dersi dışında bütün dersler teorik olarak görünmekte, uygulama bulunmamaktadır. 


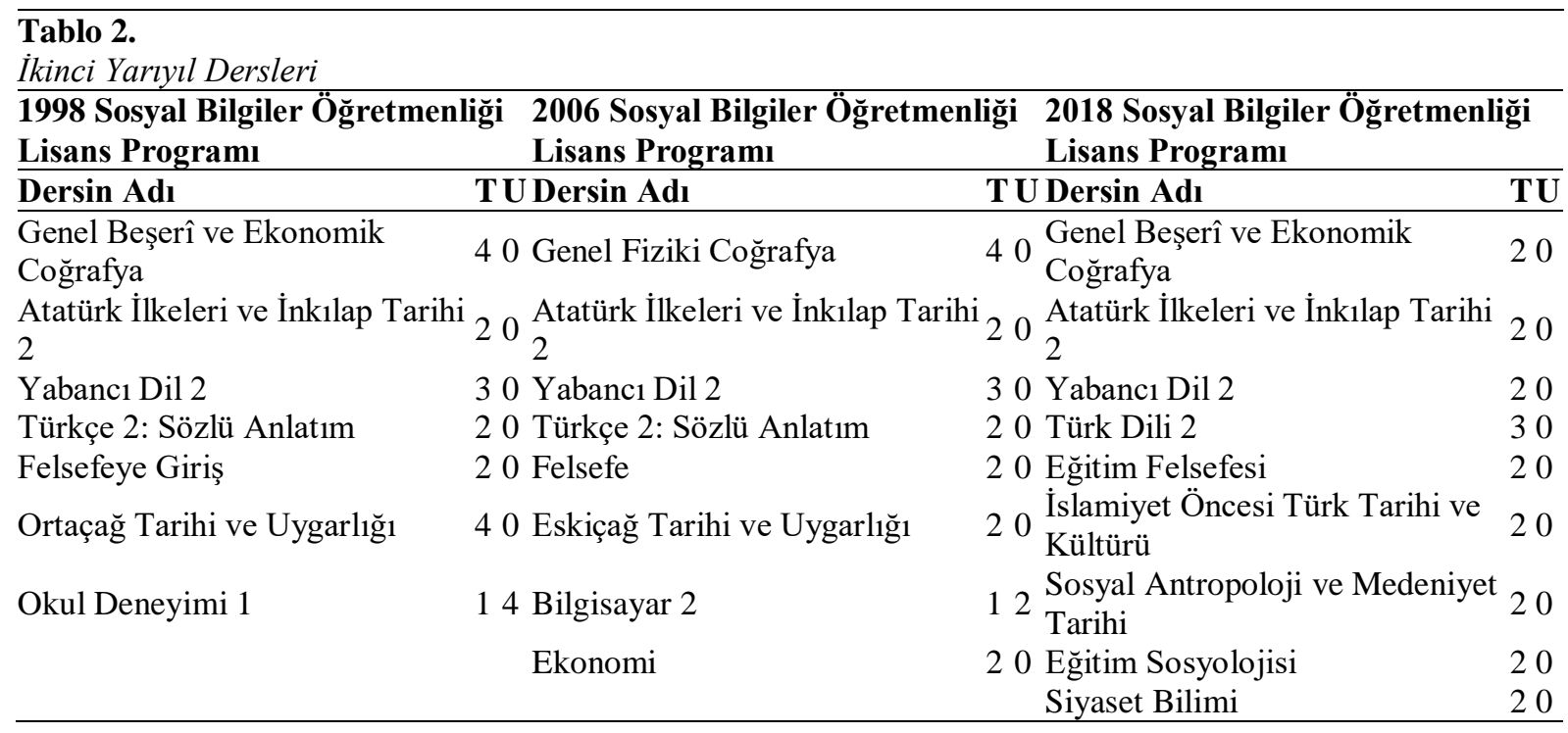

Tablo 2'de yer alan derslere baktığımızda 1998 Programı'nda 7, 2006 Programı'nda 8, 2018 Programı'nda ise 9 dersin olduğu görülmektedir. Yabancı Dil 2 ve Atatürk İlkeleri ve İnkılap Tarihi 2 derslerinin üç programda da olduğu görülmektedir. Yine birinci yarıyılda olduğu gibi 1998 ve 2006 yıllarında Türkçe 2 Yazılı Anlatım olan ders, bir ders saati artırılarak 2018 yılında Türk Dili 2 olarak programda kendine yer bulmuştur. 1998 ve 2006 yılında Felsefe dersleri varken, 2018 yılında Felsefe dersinin yerine Eğitim Felsefesi dersi programda yer almaktadır. Genel ve Beşerî Ekonomik Coğrafya dersleri 1998 ve 2018 Programlarında yer alırken 2006 yılında Genel Fiziki Coğrafya dersi bulunmaktadır. Birinci yarıyılda 1998 Programı'nda yer alan İlkçağ Tarihi ve Uygarlığı 2006 Programı'nda ikinci dönemde kendine yer bulmuştur. 1998 yılı programında Ortaçağ Tarihi ikinci dönem dersi iken bu ders 2006 yılında dördüncü dönem, 2018 Programı'nda ise üçüncü dönem dersidir. İslamiyet Öncesi Türk Tarihi ve Kültürü dersi 2018 Programı'nda ikinci dönem, 2006 ve 2018 Programlarındaysa üçüncü dönem dersidir. 2006 yılında birinci dönemde Sosyoloji olarak okutulan ders 2018 yılında Eğitim Sosyolojisi'ne dönüşmüştür. Zira Sosyoloji dersi 1998 Programı'nda da üçüncü dönemde Sosyolojiye Giriş olarak kendine yer bulmuştur. 2006 yılında ikinci dönemde bulunan Ekonomi dersi 1998 Programı'nda beşinci dönem dersi olarak yer almış, 2018 Programı'nda ise zorunlu derslerden çıkarılmıştır.

2018 yılında Sosyal Antropoloji ve Medeniyetler Tarihi olarak yer alan ders 2006 yılının dördüncü döneminde Antropoloji olarak, Siyaset Bilimi olan ders ise 2006 yılının üçüncü döneminde Siyaset Bilimine Giriş olarak yer almaktayken 1998 yılı programında Siyaset ile ilgili bir ders bulunmamaktadır.

Burada en dikkati çeken bulgu Okul Deneyimi 1 dersinin sadece 1998 Programı'nda birinci dönemde yer almasıdır. 2006 Programı'nda 7. yarıyılda okutulan ders, 2018 yılında yedinci dönemde Öğretmenlik Uygulaması 1 olarak değişmiştir. İkinci dönem dersleri içinde sadece Okul Deneyimi 1 dersinde uygulama bulunmaktadır, kalan dersler teorik olarak belirtilmiştir.

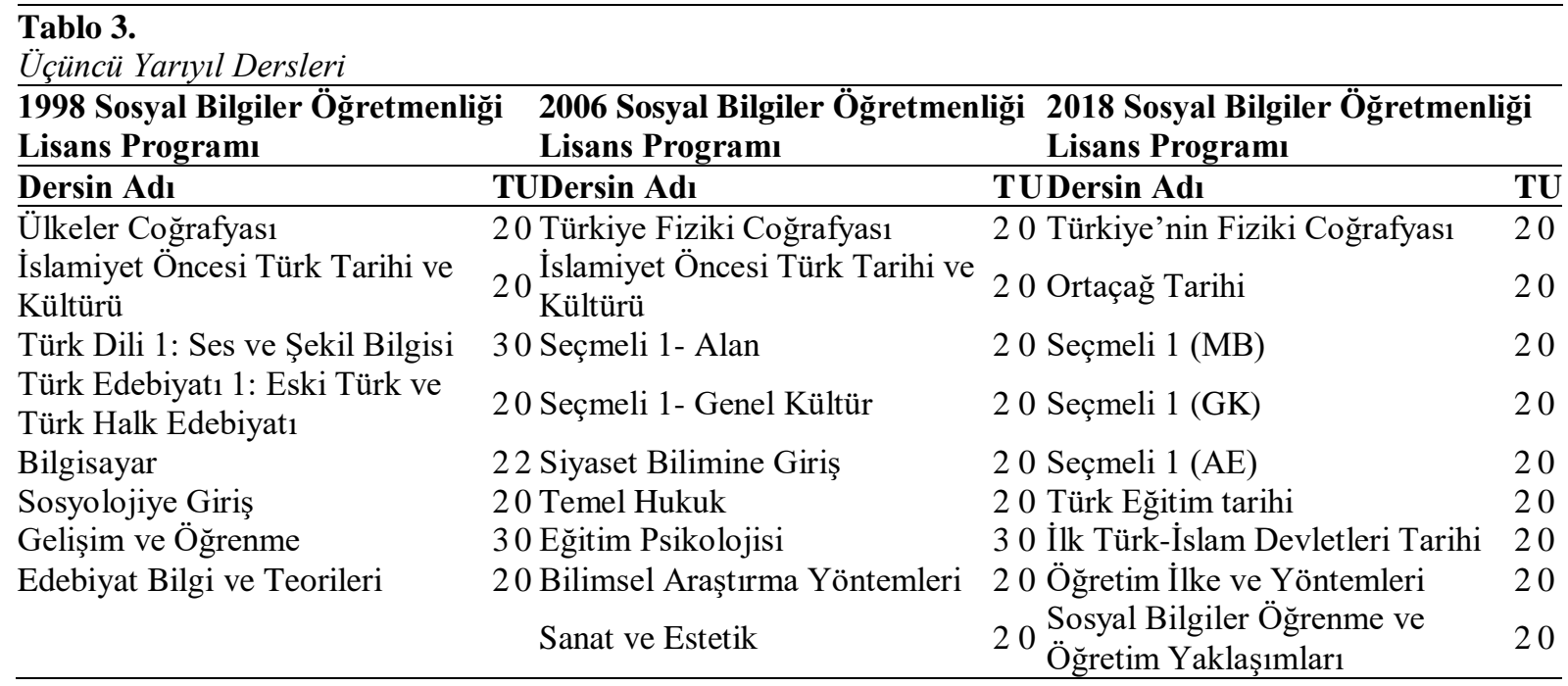


Tablo 3'te yer alan derslere baktığımızda 1998 Programı'nda 8, 2006 Programı'nda 9, 2018 Programı'nda ise 9 dersin olduğu görülmektedir. 2018 Programı'nda birinci dönemde 2 saat olarak okutulan Eğitim Psikolojisi dersi 2006 Programı’nda 3 saat, 1998 Programı’nda ise Gelişim ve Öğrenme dersi olarak karşımıza çıkmaktadır. 1998 Programı'nda yan alan uygulamasının da etkisiyle Türkçeye ait, Türk Dili 1: Ses ve Şekil Bilgisi, Türk Edebiyatı 1: Eski Türk ve Türk Halk Edebiyatı ve Edebiyat Bilgi ve Teorileri isimli üç ders bulunmaktadır. 1998 Programı'nda üçüncü dönem dersi olan Ülkeler Coğrafyası dersi 2006 yılında beşinci yarıyıl dersidir. 2018 yilında ise bu ders lisans programında bulunmamaktadır.

Türkiye Fiziki Coğrafyası dersiyse 2006 ve 2018 Programlarında üçüncü dönem dersiyken 1998 yılında dersin adı Genel ve Fiziki Coğrafya'dır. 1998 yılında bu dönemde seçmeli ders bulunmazken, 2006 Programı'nda alan ve genel kültür başlıkları altında iki, 2018 Programı'nda alan eğitimi, genel kültür ve meslek bilgisi olarak üç seçmeli ders bulunmaktadır.

2018 yılında üçüncü dönem dersi olan Türk Eğitim Tarihi dersi 2006 Programı'nda dördüncü dönem dersidir. Temel Hukuk dersi sadece 2006 Programı'nda, İlk Türk İslam Devletleri Tarihi ise sadece 2018 Programı'nda yer almaktadır. 1998 Programı'nda dördüncü dönemde Öğretimde Planlama ve Değerlendirme olan ders, 2006 yılında dördüncü yarıyılda Öğretim İlke ve Yöntemleri, 2018 yılındaysa Sosyal Bilgiler Öğrenme ve Öğretme Yaklaşımları olarak karşımıza çıkmaktadır.

Tablo 4.

Dördüncü Yarlyıl Dersleri

\begin{tabular}{|c|c|c|c|}
\hline \multirow{2}{*}{$\begin{array}{l}1998 \text { Sosyal Bilgiler Öğretmenliği } \\
\text { Lisans Programı } \\
\text { Dersin Adı }\end{array}$} & \multicolumn{3}{|c|}{$\begin{array}{l}2006 \text { Sosyal Bilgiler Öğretmenliği } 2018 \text { Sosyal Bilgiler Öğretmenliği } \\
\text { Lisans Programı } \\
\text { Lisans Programı }\end{array}$} \\
\hline & TUDersin Adı & T UDersin Adı & TU \\
\hline $\begin{array}{l}\text { Türkiye'nin Beşerî ve Ekonomik } \\
\text { Coğrafyası }\end{array}$ & $\begin{array}{l}20 \text { Genel Beşerî ve Ekonomik } \\
\text { Coğrafya }\end{array}$ & $\begin{array}{l}\text { 40̈̈rkiye'nin Beşerî ve Ekonomik } \\
\text { Coğrafyası }\end{array}$ & 20 \\
\hline Osmanlı Tarihi & 40 Seçmeli-1 (MB) & 20 Seçme & 20 \\
\hline Psikolojiye Giriş & 20 Seçmeli & $20 \mathrm{Seç}$ & 20 \\
\hline $\begin{array}{l}\text { Sosyal Bilgilerde Yazılı Sözlü } \\
\text { Edebiyat İncelemeleri }\end{array}$ & 20 Antropoloji & $20 \mathrm{Se}$ & 20 \\
\hline $\begin{array}{l}\text { Öğretimde Planlama ve } \\
\text { Değerlendirme }\end{array}$ & 32 Vatandaşlık Bilgisi & 20 Vatandaşlık Bilgisi & 20 \\
\hline $\begin{array}{l}\text { Türk Edebiyatı 2: Yeni Türk } \\
\text { Edebiyatı }\end{array}$ & Гeknoloji ve Sosyal & 20 Bilim Teknoloji ve Toplum & 20 \\
\hline Konuşma ve Yazma Eğitimi & 22 Türk Eğitim Tarihi & 20 Eğitim & 20 \\
\hline $\begin{array}{l}\text { Türk Dili 2: Cümle ve Metin } \\
\text { Bilgisi }\end{array}$ & 30 Öğretim İlke ve Yöntemleri & $30 \begin{array}{l}\text { Sosyal Bilgiler Öğretim } \\
\text { Programları }\end{array}$ & 20 \\
\hline & Ortaçağ Tarihi & $\begin{array}{l}40 \text { Topluma Hizmet Uygulamaları } \\
\text { Öğretim Teknolojileri }\end{array}$ & $\begin{array}{ll}12 \\
20\end{array}$ \\
\hline
\end{tabular}

Tablo 4'te yer alan derslere baktığımızda 1998 Programı'nda dördüncü yarıyılda 8, 2006 Programı'nda 9, 2018 Programı'nda ise 10 ders bulunmaktadır. 1998 yılında Türkiye'nin Beşerî ve Ekonomik Coğrafyası olan ders, 2006 yılında Genel ve Beşerî Ekonomik Coğrafya ismini almış, 2018 yılında ise yeniden Türkiye'nin Beşerî ve Ekonomik Coğrafyası ismiyle okutulmaya başlanmıştır. 2006 ve 2018 Programlarında dördüncü yarıyılda Vatandaşlık Bilgisi olarak yer alan ders 1998 Programı'nda beşinci dönem dersidir.

1998 Programı'nda tek dönemde dört saat olarak verilen Osmanlı Tarihi dersi, 2006 Programı'nda beşinci dönemde iki saat olarak Osmanlı Tarihi ve Uygarlığı 1, altıncı dönemde yine iki saat olarak Osmanlı Tarihi ve Uygarlığı 2 olarak, 2018 Programı'nda ise yine ikişer saat olmak üzere beşinci dönemde Osmanlı Tarihi 1, altıncı dönemde Osmanlı Tarihi 2 olarak yer almıştır.

1998 Programı'nın dördüncü döneminde seçmeli ders bulunmazken, 2006 Programı’nda alan eğitimi ve meslek bilgisi olmak üzere iki seçmeli ders bulunurken, 2018 Programı'nda meslek bilgisi, alan eğitimi ve genel kültür olmak üzere üç seçmeli ders bulunmaktadır. 2006 Programı'nda Bilim Teknoloji ve Sosyal Değişme olan ders adı, 2018 yılında Bilim Teknoloji ve Toplum olarak değişmiştir.

Bu dönemde 2018 Programı’nda Eğitimde Araştırma Yöntemleri isimli yeni bir ders bulunurken, 1998 Programı'nda bu derse mukabil kabul edilebilecek ders ismi, Sosyal Bilimlerde Araştırma Yöntemleri'dir. 2006 Programı'nda üçüncü dönem dersi olan Bilimsel Araştırma Yöntemleri dersi bulunmaktadır. 2018 yılında daha önceki programlarda yer almayan, Sosyal Bilgiler Öğretim Programları dersi bulunmaktadır.

2018 yılında bu dönemde bulunan Topluma Hizmet Uygulamaları dersi, 2006 Programı'nda beşinci dönem dersidir. Yine 2018 yılında dördüncü dönem dersi olan Öğretim Teknolojileri dersi 1998 Programı'nda beşinci 
dönemde Öğretim Teknolojileri ve Materyal Geliştirme, 2006 Programı'nın beşinci döneminde ise Öğretim Teknolojileri ve Materyal Tasarımı olarak yer almıştır. 2018 yılında ders isminden "tasarım" ve "geliştirme" kavramları çıkarılmıştır.

\begin{tabular}{|c|c|c|c|}
\hline \multicolumn{4}{|c|}{$\begin{array}{ll}1998 \text { Sosyal Bilgiler Öğretmenliği } & \begin{array}{l}2006 \text { Sosyal Bilgiler Öğretmenliği } \\
\text { Lisans Programı }\end{array}\end{array}$} \\
\hline Dersin Adı & TUDersin Adı & TUDersin Adı & $\mathbf{T U}$ \\
\hline Çocuk Edebiyatı & 30 Osmanlı Tarihi ve Uygarlığı-1 & $\begin{array}{l}20 \begin{array}{l}\text { Türk Eğitim Sistemi ve Okul } \\
\text { Yönetimi }\end{array}\end{array}$ & 20 \\
\hline Türkiye Fiziki Coğrafyası & $\begin{array}{l}20 \text { Türkiye Beşerî ve Ekonomik } \\
\text { Coğrafyası }\end{array}$ & $20 \begin{array}{l}\text { Eğitimde Ölçme ve } \\
\text { Değerlendirme }\end{array}$ & 20 \\
\hline Cumhuriyet Tarihi & 20 Yeni ve Yakınçağ Tarihi & 20 Seçmeli 3 (MB) & 20 \\
\hline Siyasal Düşünce Tarihi & İnsan Haklar1 ve Demokrasi & 20 Seçmeli 3 (GK) & 20 \\
\hline Ekonomiye Giriş & 20 Ülkeler Coğrafyası & 20 Seçmeli 3 (AE) & 20 \\
\hline $\begin{array}{l}\text { Öğretim Teknolojileri ve } \\
\text { Materyal Geliştirme }\end{array}$ & 22 Topluma Hizmet Uygulamaları & 12 Osmanlı Tarihi 1 & 20 \\
\hline Vatandaşl1k Bilgisi 1 & $\begin{array}{l}20 \text { Öğretim Teknolojileri ve } \\
\text { Materyal Tasarımı }\end{array}$ & 22 Yeni ve Yakın Çağ Tarihi & 20 \\
\hline Arkeoloji ve Sanat Tarihi & $\begin{array}{l}20 \text { Sınıf Yönetimi } \\
\text { Seçmeli-2 Genel Kültür }\end{array}$ & $\begin{array}{l}20 \text { Sosyal Bilgiler Öğretimi } 1 \\
20\end{array}$ & 30 \\
\hline
\end{tabular}

Tablo 5'te yer alan derslere baktığımızda 1998 Programı'nda beşinci yarıyılda 8, 2006 Programı'nda 9, 2018 Programı'nda ise 8 ders bulunmaktadır. 1998'de yürütülen yan alan uygulamasının etkisiyle bu dönemde Çocuk Edebiyatı dersinin olduğu görülmektedir. 1998 ve 2006 yıllarında Öğretim Teknolojileri ve Materyal tasarımı bulunurken bu ders 2018 Programı'nda Öğretim Teknolojileri olmuş ve dördüncü dönem dersi olmuştur. Yine 1998 Programı'nda seçmeli ders bulunmazken, 2006 Programı'nda bir adet genel kültür seçmeli dersi, 2018 Programı'nda ise üç adet seçmeli ders bulunmaktadır. 2006 Programı'nda bu dönemde bulunan İnsan Hakları ve Demokrasi Dersi, 2018 Programı'nda sekizinci dönemde İnsan Hakları ve Demokrasi Eğitimi olarak geçmektedir.

2006 Programı'nda beşinci dönem dersi olan Sınıf Yönetimi 1998 ve 2018 Programlarında altıncı dönem dersi olarak karşımıza çıkmaktadır. 1998 Programı'nda beşinci dönem dersi olan Cumhuriyet Tarihi, 2006 ve 2018 Programlarında Türkiye Cumhuriyet Tarihi 1 olarak yedinci dönemde okutulan bir ders olmuştur.

\begin{tabular}{|c|c|c|c|}
\hline $\begin{array}{l}\text { Tablo } 6 . \\
\text { Altınci Yartyıl Dersleri }\end{array}$ & & & \\
\hline $\begin{array}{l}1998 \text { Sosyal Bilgiler Öğretm } \\
\text { Lisans Programı }\end{array}$ & $\begin{array}{l}\text { liği } 2006 \text { Sosyal Bilgiler Öğretmenliği } \\
\text { Lisans Programı }\end{array}$ & $\begin{array}{l}2018 \text { Sosyal Bilgiler Öğret } \\
\text { Lisans Programı }\end{array}$ & \\
\hline Dersin Adı & TUDersin Adı & TUDersin Adı & TU \\
\hline Vatandaşlık Bilgisi 2 & 20 Osmanlı Tarihi ve Uygarlığı-2 & 20 Eğitimde Ahlak ve Etik & 20 \\
\hline $\begin{array}{l}\text { Sosyal Bilimlerde Araştırma } \\
\text { Yöntemleri }\end{array}$ & $20 \begin{array}{l}\text { Sosyal Bilgiler Sözlü ve Yazılı } \\
\text { Edebiyat İncelemeleri }\end{array}$ & 20 Sinıf Yönetimi & 20 \\
\hline Siyasi Coğrafya & 20 İnsan İlişkileri ve İletişim & 20 Seçmeli 4 (MB) & 20 \\
\hline Seçmeli (MB)? & 20 Çăgdaş Dünya Tarihi & 20 Seçmeli 4 (GK) & 20 \\
\hline Özel Öğretim Yöntemleri 1 & 22 Siyasi Coğrafya & 20 Seçmeli 4 (AE) & 20 \\
\hline Sınıf Yönetimi & 22 Ölçme Değerlendirme & 32 Osmanlı Tarihi 2 & 20 \\
\hline Çağdaş Dünya Tarihi & 30 Özel Öğretim Yöntemleri-1 & $\begin{array}{l}30 \text { Sosyal Bilgilerde Yazılı ve } \\
\text { Sözlü Edebiyat }\end{array}$ & 20 \\
\hline Türkçe Öğretimi & $\begin{array}{l}\text { Türk Eğitim Sistemi ve Okul } \\
22 \text { Yönetimi }\end{array}$ & $20 \begin{array}{l}\text { Siyasi Coğrafya ve Türkiye } \\
\text { Jeopolitiği }\end{array}$ & 20 \\
\hline & Seçmeli-3 Genel Kültür & 20 Sosyal Bilgiler Öğretimi 2 & 30 \\
\hline
\end{tabular}

Tablo 6'da yer alan derslere baktığımızda 1998 Programı'nda altıncı yarıyılda 8, 2006 Programı'nda 9, 2018 Programı'nda ise 9 ders bulunmaktadır. 1998 ve 2006 Programlarında Siyasi Coğrafya olarak geçen ders 2018 Programı'nda Siyasi Coğrafya ve Türkiye Jeopolitiği olarak isim ve içerik değişikliğine uğramıştır. 1998 Programı'nda bir adet, 2006 Programı'nda bir adet, 2018 Programı'nda ise üç adet seçmeli ders bulunmaktadır.

2006 Programı'nda Ölçme ve Değerlendirme olarak geçen ders, 1998 Programı'nda dördüncü dönemde Öğretimde Planlama ve Değerlendirme, 2018 Programı'ndaysa beşinci dönemde Eğitimde Ölçme ve Değerlendirme olarak isim değiştirmiştir. 2006 ve 2018 Programlarında Türk Eğitim Sistemi ve Okul Yönetimi dersi bulunurken, 1998 Programı'nda böyle bir ders bulunmamaktadır. 1998 ve 2006 Programlarında altıncı 
dönem dersi olan Özel Öğretim Yöntemleri 1 dersi, 2018 Programı’nda daha alana özel bir isimle beşinci dönemde Sosyal Bilgiler Öğretimi 1 olarak karşımıza çıkmaktadır.

1998 ve 2006 Programlarında bu dönemde Çağdaş Dünya Tarihi dersi yer alırken, 2018 Programı'nda böyle bir ders bulunmamaktadır.

Tablo 7.

Yedinci Yartyll Dersleri

\begin{tabular}{|c|c|c|c|c|c|}
\hline \multicolumn{2}{|c|}{$\begin{array}{l}1998 \text { Sosyal Bilgiler Öğretmenliği } \\
\text { Lisans Programı }\end{array}$} & \multicolumn{2}{|c|}{$\begin{array}{l}\text { 2006 Sosyal Bilgiler Öğretmenliği } \\
\text { Lisans Programı }\end{array}$} & \multicolumn{2}{|c|}{$\begin{array}{l}2018 \text { Sosyal Bilgiler Öğretmenliği } \\
\text { Lisans Programı }\end{array}$} \\
\hline Dersin Adı & & J Dersin Adı & & UDersin Adı & TU \\
\hline Çevre Sorunları Coğrafyası & 20 & Türkiye Cumhuriyet Tarihi-1 & & 0 Öğretmenlik Uygulaması 1 & 26 \\
\hline $\begin{array}{l}\text { Konu Alan1 Ders kitab1 } \\
\text { İncelemesi }\end{array}$ & & $\begin{array}{l}\text { Sosyal Bilgiler Ders Kitab1 } \\
\text { İncelemeleri }\end{array}$ & & 2 Okullarda Rehberlik & 20 \\
\hline Özel Öğretim Yöntemleri 2 & 22 & Günümüz Dünya Sorunları & & 0 Seçmeli 5 (MB) & 20 \\
\hline Okul Deneyimi-2 & 14 & Özel Öğretim Yöntemleri-2 & & 2 Seçmeli 5 (AE) & 20 \\
\hline Seçmeli 2 & 20 & Program Geliştirme & & 0 Afetler ve Afet Yönetimi & 20 \\
\hline \multirow[t]{3}{*}{ Vatandaşlık Eğitimi Semineri } & 20 & Özel Eğitim & & 0 Sanat ve Müze Eğitimi & 20 \\
\hline & & Okul Deneyimi & & 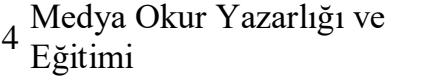 & 20 \\
\hline & & & & Türkiye Cumhuriyet Tarihi 1 & 20 \\
\hline
\end{tabular}

Tablo 7'de yer alan derslere baktı̆̆ımızda 1998 Programı'nda yedinci yarıyılda 6, 2006 Programı'nda 7, 2018 Programı'nda ise 8 ders bulunmaktadır. 1998 Programı'nda Çevre Sorunları Coğrafyası olan dersin adı, 2006 Programı'nda Günümüz Dünya Sorunları olurken, 2018 Programı'nda bu dersin yerine Afetler ve Afet Yönetimi dersi eklenmiştir.

1998 ve 2006 Programlarında yer alan Özel Öğretim Yöntemleri 2 dersi, 2018 Programı'nda altıncı dönemde Sosyal Bilgiler Öğretimi 2 olarak yer almaktadır. 1998 Programı'nda yedinci dönemde Konu Alanı Ders Kitabı İncelemesi olan dersin adı, 2006 Programı'nda alana özgü olarak Sosyal Bilgiler Ders Kitabı İncelemeleri olmuştur. Bu ders 2018 Programı'nda zorunlu dersler içinde kendine yer bulamamıştır.

1998 Programı'nda Okul Deneyimi 2 dersi bulunurken, 2006 Programı'nda ilk staj dersi yedinci yarıylda Okul Deneyimi 1 olarak karşımıza çıkmaktadır. 2018 Programı'nda ise Okul Deneyimi kaldırılmış, yerine Öğretmenlik Uygulaması 1 dersi getirilmiştir. 1998 Programı'nda bir, 2018 Programı'nda ise iki seçmeli ders bulunmaktadır. 2006 yılında Özel Eğitim olan dersin adı, 2018 Programı’nda Özel Eğitim ve Kaynaştırma olarak değişmiş̧ir ve bu ders sekizinci dönem dersi olarak karşımıza çıkmaktadır. Bu dönemde 2006 Programı'nda yer alan Program Geliştirme dersi diğer programlarda bulunmamaktadır. Ayrıca 2006 Programı'nda bazı üniversitelerde seçmeli ders olarak okutulan Sanat ve Müze Eğitimi ve Medya Okur Yazarlığı ve Eğitimi dersleri 2018 Programı'nda zorunlu ders olarak karşımıza çıkmaktadır.

\section{Tablo 8.}

Sekizinci Yartyll Dersleri

\begin{tabular}{|c|c|c|c|c|c|}
\hline \multicolumn{2}{|c|}{$\begin{array}{l}1998 \text { Sosyal Bilgiler Öğretmenliği } \\
\text { Lisans Programı }\end{array}$} & \multicolumn{4}{|c|}{$\begin{array}{ll}\text { 2006 Sosyal Bilgiler Öğretmenliği } & \begin{array}{l}2018 \text { Sosyal Bilgiler Öğretmenliği } \\
\text { Lisans Programı }\end{array} \\
\text { Lisans Programı }\end{array}$} \\
\hline Dersin Adı & T U & Dersin Adı & & U Dersin Adı & TU \\
\hline Günümüz Di & 20 & Türkiye Cum & & j Öğretmenlik Uy & 26 \\
\hline İnsan İlişkkile & 20 & Sosyal Pro & & 2 Özel Eğitim ve Kaynaştırma & 20 \\
\hline Öğretmenlik Uygulaması & 26 & Drama & & 2 Seçmeli 6 (MB) & 20 \\
\hline Seçı & 20 & Rehb & 30 & $\mathrm{Sec}$ & 20 \\
\hline \multirow[t]{3}{*}{ Rehberlik } & 30 & Öğretmenlik Uygulaması & & 6 Türkiye Cumhuriyet Tarihi 2 & 20 \\
\hline & & $\begin{array}{l}\text { Seçmeli-2 Öğretmenlik Meslek } \\
\text { Bilgisi }\end{array}$ & & İnsan Hakları ve Demokrasi & 0 \\
\hline & & & & Karakter ve Değer Eğitimi & 20 \\
\hline
\end{tabular}

Tablo 8'de yer alan derslere baktığımızda 1998 Programı'nda sekizinci yarıyılda 5, 2006 Programı'nda 6, 2018 Programı'nda ise 7 ders bulunmaktadır. 2006 Programı'nda bir önceki dönem okutulan Günümüz Dünya Sorunları 1998 Programı'nda sekizinci dönem dersidir. 1998 Programı'nda bu dönemde bulunan İnsan İlişkileri ve İletişim dersi 2006 Programı'nın altıncı dönem dersidir, 2018 Programı'nda böyle bir ders bulunmamaktadır. 1998 ve 2006 Programlarında bir adet, 2018 Programı'ndaysa 2 adet seçmeli ders bulunmaktadır. 1998 Programı'nda tek dönem olarak okutulan Cumhuriyet Tarihi dersi, 2006 ve 2018 Programlarında Türkiye Cumhuriyet Tarihi adını almış ve bunun ikinci bölümü sekizinci yarıyıl dersi olarak yer almıştır. Üç program içinde sadece 2006 Programı'nda Drama dersi bulunmaktadır. Üç programda da sekizinci dönem dersi olarak 
Öğretmenlik Uygulaması dersi bulunmaktadır. Sadece 2018 Programı’nda Karakter ve Değer Eğitimi adı altında bir ders bulunmaktadır.

\section{2. İkinci araştırma sorusu ile ilgili bulgular}

“1998, 2006 ve 2018 Sosyal Bilgiler Öğretmenliği Lisans Programlarında teorik ve uygulamalı derslerin dağılımı nasıldır?” alt problemine ilişkin veriler Tablo 9'da verilmiştir.

\section{Tablo 9.}

Teori ve Uygulama Dă̆ılımı

\begin{tabular}{lllll}
\hline Lisans Programları & Ders sayısı & Teori & Uygulama & $\begin{array}{l}\text { Toplam } \\
\text { (Saat) }\end{array}$ \\
\hline 1998 Sosyal Bilgiler Öğretmenliği Lisans Programı & 57 & 131 saat & 32 saat & 163 saat \\
2006 Sosyal Bilgiler Öğretmenliği Lisans Programı & 61 & 142 saat & 28 saat & 170 saat \\
2018 Sosyal Bilgiler Öğretmenliği Lisans Programı & 68 & 140 saat & 14 saat & 154 saat \\
\hline
\end{tabular}

Tablo 9'da programlardaki toplam ders sayıları ve teorik-uygulama dersleri ile ilgili bilgiler verilmiştir. Toplam ders sayısı 1998 Programı'ndan 2018 Programı'na bir artış göstermiş ve 57'den 68'e yükselmiştir. Teorik dersler 1998 Programı'ndan 2018 Programı'na bir artış göstermiştir. Uygulama dersleri ise 1998 Programı'ndan 2018 Programı'na doğru düzenli olarak azalmıştır. 1998 Programı'ndaki uygulamalı dersler 32 saatken, 2018 yılında yüzde elliden fazla bir düşüşle uygulamalı dersler 14 saate düşmüştür. Toplam ders saati ve toplam ders sayısı bir arada değerlendirildiğinde ders sayılarının arttı̆̆

\section{3. Üçüncü araştırma sorusu ile ilgili bulgular}

“1998, 2006 ve 2018 Sosyal Bilgiler Öğretmenliği Lisans Programlarında seçmeli derslerin dağılımı nasıldır?” alt problemine ilişkin veriler Tablo 10’da verilmiştir.

\begin{tabular}{|c|c|c|c|c|c|c|c|}
\hline $\begin{array}{l}\text { Tablo 10. } \\
\text { Seçmeli Derslerin Dă̆ılımı }\end{array}$ & & & & & & & \\
\hline Lisans Programları & & & & & & & \\
\hline 1998 Sosyal Bilgiler Öğretmenliği & & & & & & & Toplam Saat \\
\hline Lisans Programı & & & & & & & 3 ders ve 6 saat \\
\hline & Mesle & Bilgisi & Gene & ültür & Alan & itimi & Toplam Saat \\
\hline 2006 Sosyal Bilgiler Ogretmenliği & Ders & Saat & Ders & Saat & Ders & Saat & \\
\hline & 2 & 4 & 3 & 6 & 2 & 4 & 7 ders ve14 Saat \\
\hline & Mesle & Bilgisi & Gene & ültür & Alan & itimi & Toplam Saat \\
\hline 2018 Sosyal Bilgiler Ogretmenligi & Ders & Saat & Ders & Saat & Ders & Saat & \\
\hline Lisans Programı & 6 & 12 & 4 & 8 & 6 & 12 & 16 ders ve 32 Saat \\
\hline
\end{tabular}

Tablo 10'da programlarda yer alan seçmeli derslere ilişkin bulgulara yer verilmiştir. Seçmeli derslerin 1998 ve 2018 Programları arasında ders ve saat bazında beş kat arttığı görülmektedir. 1998 Programı'nda seçmeli dersler için bir ayrım söz konusu değilken, 2006 ve 2018 Programlarında meslek bilgisi, genel kültür ve alan eğitimi şeklinde bir ayrıma gidilmiş ve en çok seçmeli ders, meslek bilgisi grubunda yer almıştır. Zorunlu dersler ile seçmeli dersler açısından bazı derslerde büyük benzerlik bulunmaktadır. Örneğin zorunlu ders olarak alan eğitimi kapsamında Sanat ve Müze Eğitimi diye bir ders varken, seçmeli dersler içinde meslek bilgisi derslerinde Müze eğitimi isimli bir ders daha bulunmaktadır. Ayrıca zorunlu dersler içinde alan eğitimi kapsamında İnsan Hakları ve Demokrasi Eğitimi isimli bir ders bulunurken, genel kültür seçmeli dersleri içinde aynı isimle bir seçmeli ders daha bulunmaktadır.

\subsection{Dördüncü araştırma sorusu ile ilgili bulgular}

“1998, 2006 ve 2018 Sosyal Bilgiler Öğretmenliği Lisans Programlarında sosyal bilimler disiplinlerinin dağılımı nasıldır?" alt problemine ilişkin veriler Tablo 11'de verilmiştir.

\section{Tablo 11.}

Sosyal Bilimlerin Sosyal Bilgiler Programlarında Yer Alma Durumu

\begin{tabular}{llll}
\hline Disiplinler & $\begin{array}{l}\text { 1998 Sosyal Bilgiler } \\
\text { Öğretmenliği Lisans } \\
\text { Programı }\end{array}$ & $\begin{array}{l}\text { 2006 Sosyal Bilgiler } \\
\text { Öğretmenliği Lisans } \\
\text { Programı }\end{array}$ & $\begin{array}{l}\text { 2018 Sosyal Bilgiler } \\
\text { Öğretmenliği Lisans } \\
\text { Programı }\end{array}$ \\
\hline Tarih & 8 ders ve 22 saat & 11 ders ve 24 saat & 9 ders ve 18 saat \\
Coğrafya & 8 ders ve 20 saat & 7 ders ve 16 saat & 6 ders ve 12 saat \\
Vatandaşlik & 3 ders ve 6 saat & 2 ders ve 4 saat & 2 ders ve 4 saat \\
\hline
\end{tabular}




\begin{tabular}{|c|c|c|c|}
\hline \multicolumn{4}{|c|}{$\begin{array}{l}\text { Tablo 11. devamı } \\
\text { Sosyal Bilimlerin Sosyal Bilgiler Programlarında Yer Alma Durumu }\end{array}$} \\
\hline Disiplinler & $\begin{array}{l}1998 \text { Sosyal Bilgiler } \\
\text { Öğretmenliği Lisans } \\
\text { Programı }\end{array}$ & $\begin{array}{l}2006 \text { Sosyal Bilgiler } \\
\text { Öğretmenliği Lisans } \\
\text { Programı }\end{array}$ & $\begin{array}{l}2018 \text { Sosyal Bilgiler } \\
\text { Öğretmenliği Lisans } \\
\text { Programı }\end{array}$ \\
\hline Psikoloji & 1 ders ve 2 saat & 1 ders ve 2 saat & - \\
\hline Sosyoloji & 1 ders ve 2 saat & 1 ders ve 2 saat & - \\
\hline Ekonomi & 1 ders ve 2 saat & 1 ders ve 2 saat & - \\
\hline Hukuk & - & 1 ders ve 2 saat & - \\
\hline Arkeoloji & 1 ders ve 2 saat & 1 ders ve 2 saat & - \\
\hline Felsefe & 1 ders ve 2 saat & 1 ders ve 2 saat & - \\
\hline Antropoloji & - & 1 ders ve 2 saat & 1 ders ve 2 saat \\
\hline Siyaset Bilimi & - & 1 ders ve 2 saat & 1 ders ve 2 saat \\
\hline Toplam & 24 ders ve 58 saat & 28 ders ve 60 saat & 19 ders ve 38 saat \\
\hline
\end{tabular}

Tablo 11'de sosyal bilim disiplinlerinin programlara dağılımı verilmiştir. 1998 ve 2006 Programlarında saat bazında sosyal bilimlere ayrılan süre birbirine yakındır. 2018 Programı'nda ise bu süre neredeyse yarı yarıya düşmüş ve 38 saat olarak yer almıştır. 1998 Programı'nda 9 sosyal bilim disiplini, 2006 yılında 11 sosyal bilim disiplini, 2018 yılındaysa 5 sosyal bilim disiplini programda kendisine yer bulmuştur. Üç programın ortak özelliği ise ders sayıları değişmekle beraber tarih ve coğrafya derslerinin ağırlıklı olarak yerlerini muhafaza etmiş olmasıdır.

\subsection{Beşinci araştırma sorusu ile ilgili bulgular}

“1998, 2006 ve 2018 Sosyal Bilgiler Öğretmenliği Lisans Programlarında meslek bilgisi, genel kültür ve alan eğitimi derslerinin dağılımı nasıldır?” alt problemine ilişkin bilgiler Tablo 12 'de sunulmuştur.

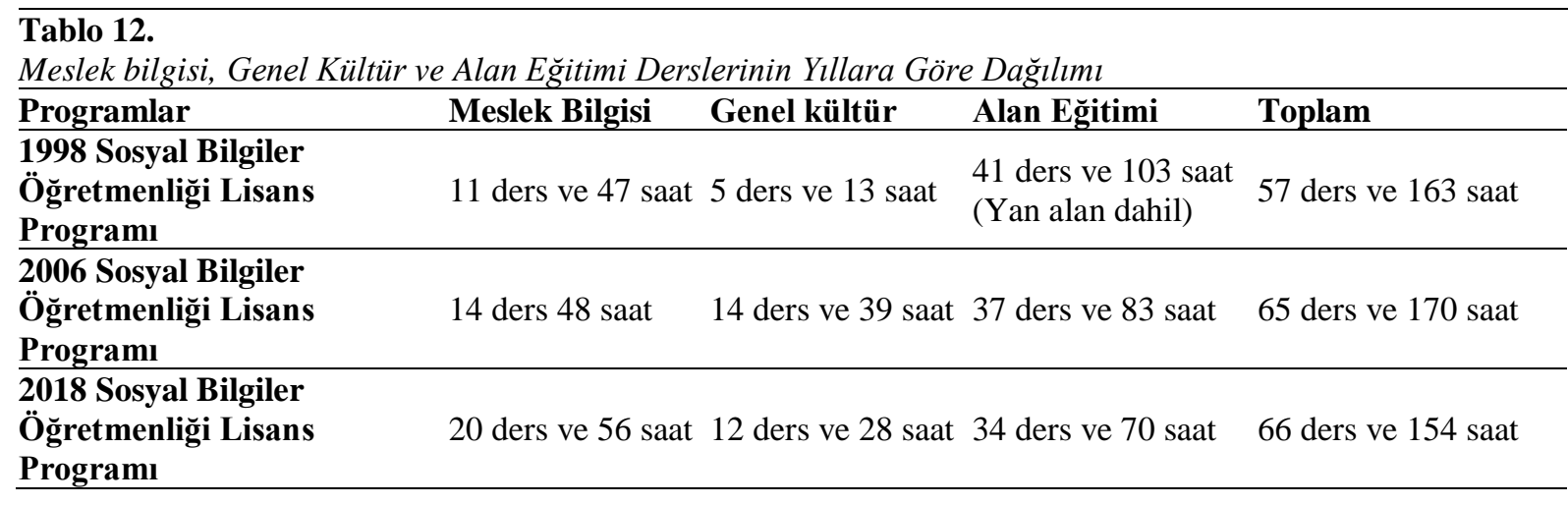

Tablo 12'ye bakıldığında meslek bilgisi grubuna giren dersler, kademeli olarak 1998'den 2018 y1lına kadar ders ve saat olarak artış göstermiştir. Bunun tam tersine alan eğitimine ilişkin dersler 1998 yılından 2018 yılındaki programa kadar ders ve saat bakımından azalmıştır. Genel kültür dersleri ise sosyal bilgiler öğretmenliği lisans programlarında 1998 yılında 5 ders ve 13 saat olarak bulunurken, 2006 yılındaki programda 14 ders ve 39 saate yükselmiş, 2018 Programı'nda ise 12 ders ve 28 saate düşmüştür. Toplam ders sayıları ve saatleri açısından programlar değerlendirildiğinde ders sayısı düzenli olarak artarken, 1998 Programı'nda sosyal bilgiler ögrretmenliği lisans programı toplam 163 saat iken, 2006 Programı'nda 170 saate yükselmiş, 2017 Programı'nda ise 154 saate düşmüş ve en düşük seviyeye ulaşmıştır. Buradan anlaşılan; sosyal bilgiler öğretmenliği lisans programlarında ders sayıları artarken, ders başına düşen saat sayısı azalmıştır.

$\mathrm{Bu}$ üç sosyal bilgiler lisans programı hazırlanışı ve ortaya konuluşu açısından ana hatları ile de şu şekilde değerlendirilebilir:

1998 Sosyal Bilgiler Öğretmenliği Lisans Programı ile ilgili hazırlanan kitabın başlangıç kısmında program geliştirmeye yön veren temel ilkelere, güncelleme ve yeniliklere ilişkin açıklamalara yer verilmiştir. Burada 1997-1998 öğretim yılında uygulanmaya başlanan sekiz yıllık zorunlu ilköğretim düzeyindeki sınıf ve branş öğretmeni ihtiyacı, 1994 yılında başlayan ve Dünya Bankası ile ortak yürütülen proje kapsamında program geliştirme çalışması yapıldığına vurgu yapılmıştır. Program geliştirme için kimlerin ve hangi alanlardan akademisyenlerin katıldığına ilişkin bilgi verilmemiştir (YÖK, 1998).

2006 Öğretmenlik Lisans Programı'nın da zorunlu ilköğretim uygulaması ve 2003 yılından beri ülkemizin de içinde yer aldığı "Avrupa Yükseköğretim Alanı” kapsamında lisans programlarından beklenen öğrenme çıktılarını tanımlamak ve değerlendirmek amacıyla, 2003-2004 eğitim-öğretim yılından itibaren uygulanmak 
üzere Millî Eğitim Bakanlığı tarafindan ilköğretim programlarında yapılan değişikliklere dayanılarak yenilendiği ifade edilmektedir. Yirmi beş kişinin katılımıyla yedi günlük bir çalıstay sonunda bir taslak hazırlanmış, ardından görüş almak için ilgili dekanlıklara gönderilmiştir. Ancak bu taslak çalışmasına kimlerin ve hangi alanlardan akademisyenlerin katıldığına ilişkin bilgi verilmemiştir. Ayrıca 1998 Programı’ndaki kadar detaylara yer verilmediği görülmektedir (YÖK, 2006).

2018 'de yapılan öğretmen yetiştirme çalışmaları ile ilgili daha önceden yapılan program geliştirme çalışmalarında orta öğretim öğretmenliği programlarıyla ilgili bir güncelleme yapılmaması, üniversiteler ve fakülteler arasında haftalık ders saati, ders kredisi ve AKTS yönünden uyumsuzlukların olması, daha önce MEB ve YÖK tarafindan yayınlanan strateji planları ve belgeleri, Bologna süreci, yeni bir programa duyulan ihtiyaç, programın güncellenmesinin gerekçelerini oluşturmuştur. Ayrıca öğretmen adaylarını kültürel ve entelektüel yönden donanımlı ve ahlaki ve kültürel bir lider olarak yetiştirmek de gerekçeler içinde yer almıştır. Yürürlüğe giren yeni öğretmenlik eğitimi YÖK'ün ifadesiyle iki yıllık bir zaman diliminde gerçekleştirilmiştir. Bu süreçte iki gün ve birer gün süren çeşitli çalıştaylar ve toplantılar yapılmıştır. Ancak bu sürecin sonunda "Öğretmen Yetiştirme Lisans Programları" ismiyle hazırlanan kitapta çalıştay ve toplantılara ilişkin bilgiler sunulmamıştır.

Üç programın ortak yönleri bulunmaktadır. Örneğin, üç programda da program geliştirme sürecine kimlerin katıldığı, hangi alanlardan akademisyenlerin katkı sağladığı ne isim olarak ne de çalışma alanı olarak net bir şekilde verilmemiştir. Üç programda da detaylı olarak program geliştirme ve güncellemeye ilişkin gerekçelere yer verilmemiştir. Örneğin, 2006 Programı'nda çağımızın gerektirdiği bilgi ve beceriye sahip öğretmen adayları yetiştirmek vurgusu yapılmış ama bu bilgi ve becerilerin neler olduğuna ilişkin detaylar sunulmamıştır. Benzer şekilde 2018 Programı'nda yurt içinden ve yurt dışından pek çok yayının incelendiği ve bilimsel sonuçlara göre değişikliklerin yapıldığı ifade edilmiş, ancak yüzeysel ifadeler dışında detaylar verilmemiştir. YÖK tarafindan hazırlanan bir kitapta ilgili detayların ve kaynakların olmayışı düşündürücüdür. Ayrıca 2018 lisans programları için hazırlanan kitapta baskı tarihi de verilmemiştir. Bu kaynağa yöntem kısmında verilen erişim adresi ile parçalar hâlinde internetten ulaşılabilmektedir. Üç program içinde en detaylı açıklamalar ve gerekçeler 1998 Programı'nda yer almaktadır. 1998 Programı'nda, neden değişikliğe gidildiği çeşitli başlıklar hâlinde detayları ile beraber yazılmıştır.

Üç programda da derslere ilişkin kur tanımları yapılmış, derslerin içeriğine ilişsin alt başlıklar verilmiştir. 2018 Programı'nda derslerin isimleri ve içerikleri değiştirilmiş, ama buna neden ihtiyaç duyulduğuna ilişkin açıklamalar yapılmamıştır. Örneğin, "Eğitim Bilimine Giriş" dersi "Eğitime Giriş" olarak, "Ölçme ve Değerlendirme" dersi "Eğitimde Ölçme ve Değerlendirme" olarak değiştirilmiş, ancak değişikliğe neden ihtiyaç duyulduğu belirtilmemiştir.

Üç program çeşitli açılardan birbirinden ayrılsa da ağırlıklı olarak bilgi aktarmak temel prensip olarak karşımıza çıkmaktadır. Sosyal bilgiler lisans öğretmen yetiştirme programlarında öğretmen adaylarının değer ve beceri kazanması açısından yeterince ders ve ders içeriği olmadığı dikkat çekmektedir.

1998, 2006 ve 2018 yıllarında yayımlanan öğretmenlik lisans programları ile ilgili, YÖK tarafından hazırlanan kitaplara bakıldığında yeterince ayrıntıya ulaşılamadığı görülmektedir. Ancak günümüzden 22 sene önce yapılan 1998 öğretmen lisans yetiştirme programı için hazırlanan kitapta diğerlerine göre daha çok gerekçeye ve ayrıntıya yer verildiği gözlemlenmektedir.

\section{TARTIŞMA ve SONUÇ}

Sosyal bilgiler öğretmenliği lisans programında son yirmi yılda yaşanan gelişmeleri ve değişimleri betimlemeyi amaçlayan araştırmanın sonuçları şu şekildedir: Sosyal bilgiler öğretmenliği lisans programları genel olarak değerlendirildiğinde, 1998 Programı Türkçe yan alan dersleri, 2006 Programı sosyal bilgileri oluşturan sosyal bilim disiplinleri ve 2018 Programı ise meslek bilgisi başlığı altındaki derslerin çokluğu ile dikkat çekmektedir. Sosyal bilgiler öğretmenliği lisans programı geldiği son nokta itibarıyla, uygulama dersleri sayısının son derece azaldığı, sosyal bilgilerin kapsamını oluşturan pek çok sosyal bilim disiplininin ana derslerden kaldırıldığı, derslerin başına veya sonuna "eğitim" kavramının eklendiği bir program olarak tespit edilmektedir.

Toplam ders sayısı açısından programlara bakıldı̆̆ında 1998 Programı'nda ders sayısı 57 iken, 2006 Programı'nda 61'e, 2018 Programı'nda ise 68'e yükselmiştir. Buna karşılık sosyal bilgiler öğretmen adaylarının öğretmenlik eğitimi bağlamında aldıkları dersler 1998 Programı'nda 163 saat iken, 2006 Programı'nda 170 saate yükselmiş, ardından 2018 Programı'nda ise 154 saate düşmüştür. Gelinen son noktada alınan derslerin fazlalaştığı, ders saatlerinin ise azaldığı görülmektedir.

1998 Programı'nda 32 saat olan uygulama dersleri 2006 Programı'nda 28 saate, 2018 Programı'nda ise 14 saate düşmüştür. Buna karşlık 1998 Programı'nda 131 saat olan teorik derslerin, 2018 Programı'nda 140 saate kadar yükseldiği görülmektedir. Bu iki sonuç bir arada değerlendirildiğinde öğretmenlik eğitiminde uygulamanın göz ardı edildiği, bunun yerine verilebildiği kadar çok teorik derse yer verildiği görülmektedir. Literatürde var olan 
pek çok araştırmada bu durumun tersini gerektiren sonuçlar bulunmaktadır. Örneğin, öğretmen adayları ile yapılan çalışmalarda öğretmen adayları, sosyal bilgiler öğretmenliği lisans programından daha çok uygulama beklediklerini, yeterli uygulama yapmadıkları için teorik derslerden de mesleki anlamda yeterince faydalanamadıklarını, bilgiler ezberden öteye geçmediği için ileride öğretmen olduklarında bilgileri nasıl kullanacaklarını bilemediklerini ifade etmişlerdir (Akhan, 2015; Karasu Avcı, 2017; Sağdıc, 2018; Tonga, 2016; Ünlü, vd. 2015; Yılmaz, 2009; Yılmaz \& Tepebaş, 2011;). Bununla beraber sosyal bilgiler öğretmenleri ile yapılan çalışmalarda da sosyal bilgiler öğretmenleri kendilerini bilgi aktarıcısı olarak tanımlamışlar ve yeterince uygulamaya yer veremediklerini ifade etmişlerdir (Çulha Özbaş, 2012, Tonga, 2016). Literatürde bu ve benzeri pek çok çalışma sonucu varken sosyal bilgiler öğretmenliği lisans programında uygulamanın azaltılmasına bir anlam vermek son derece zor görünmektedir.

Burada sosyal bilgiler öğretmen adayları ve sosyal bilgiler öğretmenleri ile yapılan çalışmalar bir arada değerlendirildiğinde öğretmenlerin lisans eğitimleri boyunca aldıkları teorik derslerin öğretmenlik kimliğini de şekillendirdiği görülmektedir. Zira sosyal bilgiler öğretmen adayları derslere giren akademisyenlerin pek çoğunun sunuş yoluyla ve düz bir anlatımla dersleri işlediklerini belirtmişlerdir (Kaymakcı \& Akbaba, 2014; Şahin \& Güvercin Çetinoğlu, 2016; Tonga, 2016; Yılmaz, 2009). Bu sonuçlar bir arada değerlendirildiğinde sosyal bilgiler öğretmenliği lisans programında uygulamaya ilişkin derslerin eksikliği, öğretmenlerin istenilen donanıma sahip olmadan ve bilgileri kullanma konusunda yeterince olgunlaşmadan mezun olacakları kaygısını doğurmaktadır.

Seçmeli dersler açısından bakıldığında 1998 Programı'nda sadece 3 seçmeli ders varken bu sayı 2006 Programı'nda 7 derse, 2018 Programı'nda ise 16 derse yükselmiştir. Böylece Bologna sürecinde derslerin en az \%25'inin seçmeli olma zorunluluğunun büyük ölçüde sağlandığı görülmektedir (Sağdıç, 2018). Seçmeli dersler 2018 Programı'nda çok çeşitlilik arz etmektedir. Ancak bazı zorunlu derslerin içerikleri ve isimleri neredeyse seçmeli dersler ile aynıdır. Örneğin, zorunlu ders olarak alan eğitimi kapsamında Sanat ve Müze Eğitimi diye bir ders varken, seçmeli dersler içinde meslek bilgisi derslerinde Müze Eğitimi isimli bir ders daha bulunmaktadır. Ayrıca zorunlu dersler içinde alan eğitimi kapsamında İnsan Hakları ve Demokrasi Eğitimi isimli bir ders bulunurken, genel kültür seçmeli dersleri içinde aynı isimle bir seçmeli ders daha bulunmaktadır (YÖK, 2018).

Programlar, sosyal bilimlerin sosyal bilgiler öğretmenliği lisans programlarında nasıl yer aldıkları açısından değerlendirildiğinde, 1998 Programı'nda tarih, coğrafya, vatandaşlık, psikoloji, ekonomi, arkeoloji ve felsefe olmak üzere 8 sosyal bilim disiplini bulunduğu görülmektedir. Bunlar içinde tarih dersleri 22 saat, coğrafya dersleri ise 20 saattir. 2006 Programı'nda tarih, coğrafya, vatandaşlık, sosyoloji, sosyal psikoloji, ekonomi, hukuk, arkeoloji, felsefe, antropoloji ve siyaset bilimi olmak üzere 11 sosyal bilim disiplini yer almaktadır. Bunlar içinde tarih dersleri 24 saat, coğrafya dersleri ise 16 saattir. 2018 Programı'ndaysa tarih, coğrafya, vatandaşlık, antropoloji ve siyaset bilimi olmak üzere 5 sosyal bilim disiplini yer almaktadır. Burada tarih dersleri 18 saat, coğrafya dersleri ise 12 saattir. En son gelinen noktada sosyal bilgiler öğretmenliği lisans programında tarih ve coğrafya derslerinin ağırlığı azaltılırken, sosyal bilimlere ilişkin pek çok disiplinin ana derslerden çıkarıldığı ve seçmeli derslere koyulduğu görülmektedir. Ancak literatürde sosyal bilgiler öğretmen adayları ile yapılan çalışmalarda katılımcıların disiplinler arasında nasıl bağ kuracaklarını bilemedikleri sonucu bulunmaktadır (Kaya \& Bursa, 2018). Demircioğlu (2006) sosyal bilgiler öğretmen adayları ile yaptığı çalışmada katılımcıların sosyal bilimler kavramını tam olarak bilemedikleri sonucuna ulaşmıştır. Katılımcıların bir bölümü bu dersleri gereksiz görmektedir. Öğretim elemanlarının ders anlatım tarzına göre öğretmen adaylarının özellikle düz anlatımdan dolayı bu dersleri gereksiz gördükleri sonucuna ulaşan çalışmalar bulunmaktadır (Akhan, 2015; Demircioğlu, 2006; Karasu Avc1, 2017; Şahin \& Güvercin Çetinoğlu, 2016; Yılmaz, 2009). Demircioğlu'na göre (2006) bu durumun sebebi, bu derslerin üretimden uzak, ezbere dayalı ve yaşamla bağlantısız bir şekilde işlenmesidir. Tonga'ya (2012) göre bu durumun en önemli sebeplerinden biri, sosyal bilimlere ilişkin derslerin öğretmenlik programında pür olarak ele alınması ve sosyal bilgiler dersinde nasıl kullanılacağına ilişkin örneklerin yeterince sunulmayışıdır. Başka bir çalışmada sosyal bilgiler öğretmen adaylarının lisans eğitiminde sosyal bilgiler ile ilgili konuları yeterince öğrenemedikleri sonucuna ulaşılmıştır (Kaymakcı \& Akbaba, 2014). Bu kapsamda 2018 Programı'nda hukuk, sosyoloji, ekonomi, arkeoloji disiplinlerine ilişkin derslerin zorunlu ders kapsamından çıkartılması sosyal bilgiler anlayışından bir sapma olarak da nitelendirilebilir. Alan bilgisi derslerinin azaltılması, öğrencilerin bu çerçevede ortaya çıkacak bilgi eksikliğini gidermek adına dershanelere daha fazla yönelmesi gibi başka bir soruna da neden olabilir (Sağdıç, 2018). Ayrıca ortaokul öğrencilerinin bir sosyal bilimci gibi düşünerek çevrelerindeki problemlere yaklaşmalarını sağlayacak olan öğretmen adaylarının, sosyal bilimlerin eğitimsel amaçlarından, metot ve yöntemlerinden yeterince haberdar olmamaları (Demircioğlu, 2006) öğrenciler için de olumsuzluklar doğuracaktır.

Burada Hukuk ve Ekonomi gibi günlük yaşamda öğrencileri doğrudan ilgilendiren dersleri öğretmenlik eğitiminden çıkarmış olmak, ileride ortaokul öğrencilerinin de bu alana ilişkin kavram ve değerleri yeterince alamayacağı kaygısını ortaya çıkarmaktadır. Zira ailelerin ekonomik konularda karar alma sürecine çocukların aktif katıldığını düşündüğümüzde (Aymankuy \& Ceylan, 2013; Gülerarslan, 2011) bu durumda öğretmen 
adaylarının Ekonomi dersini öğrenciler için nasıl yapılandıracağını bilemeyeceği kaygısı doğmaktadır. Günümüzde hukuk bağlamında çocuk hukuku ve çocuk hakları sıklıkla çalışılmasına rağmen, sosyal bilgiler ögretmenliği lisans programında bunlara ilişkin doğrudan bir dersin olmayışı günlük yaşam açısından sıkıntılar oluşturabilir. Çünkü bir vatandaş olarak çocuğun haklarını etkili şekilde kullanması ve ekonomik değerlere sahip olması, sosyal bilgiler eğitimin önemli amaçlarındandır.

2018 Programı'nda bazı derslerin isimleri ve içerikleri değişmiştir. Özellikle derslerin isimlerinin başına veya sonuna "eğitim" kavramının eklendiği görülmektedir. Örneğin, Sosyoloji dersinin yerini Eğitim Sosyolojisi, Felsefe dersinin yerini Eğitim Felsefesi, İnsan Hakları ve Demokrasi dersinin yerine İnsan hakları ve Demokrasi Eğitimi dersi almıştır. Eğitim Bilimine Giriş dersinin ismi değişmiş ve Eğitime Giriş olmuştur. Önceden Ölçme ve Değerlendirme olan ders, Eğitimde Ölçme ve Değerlendirme olarak değişmiştir. Öğretim Teknolojileri ve Materyal Tasarımı dersi YÖK'ün ifadesiyle "Bölüm ve anabilim dalları arasında hep bir ihtilaf konusu olduğundan kaldırılarak bunun yerine içeriği güncellenerek 'Öğretim Teknolojileri' adıyla bir ders yer almıştır." (YÖK, 2018). Materyal geliştirmeninse ilgili alanın öğretimine yönelik derslerde ve öğretmenlik uygulaması dersleri kapsamında yer alacağı ifade edilmiştir (YÖK, 2018). Her öğretmen adayının alanına ilişkin geleneksel ya da dijital materyal geliştirme konusunda belli bir beceriye sahip olması beklenir. Ayrıca öğretim teknolojilerindeki hızlı gelişmeler ve akademik çalışmalar göstermektedir ki öğretim teknolojilerinin iki saatlik teorik bir ders olarak öğretmen adaylarına verilmesi yeterli düzeyde görülmemektedir (Sağdıç, 2018). YÖK'ün açıklamalarına dayanarak dersin isminin ve içeriğinin neden değiştiğine yönelik yorum yapmak son derece zor görünmektedir.

Yıllara göre programlar değerlendirildiğinde 1998 Programı'nda meslek bilgisi dersleri 11 ders ve 47 saat, 2006 Programı'nda 14 ders ve 47 saat, 2018 Programı'ndaysa 20 ders ve 56 saat olarak karşımıza çıkmakta ve meslek bilgisi derslerinin ders ve saat bakımından arttığı görülmektedir. 2006 Programı'nda YÖK'ün hazırladığı ilgili kitapta "alan ve alan eğitimi" tabiri geçerken, 2018 Programı'nda sadece "alan eğitimi" tabiri kullanılmış ve pür dersler de alan eğitimi kapsamında değerlendirilmiştir. 1998 Programı'nda alan ve alan eğitimine ilişkin dersler 41 ders ve 103 saat, 2006 Programı'nda 37 ders ve 83 saat, 2018 Programı'ndaysa 34 ders ve 70 saat olarak düzenli bir azalış göstermektedir. Genel kültür dersleri 1998 Programı'nda 5 ders ve 13 saat, 2006 Programı'nda 14 ders ve 39 saat, 2018 Programı'ndaysa 12 ders ve 28 saat olarak karşımıza çıkmakta ve bir artış ve bir azalış görülmektedir. Sosyal bilgiler öğretmenliği lisans programının son durumuna bakılarak, meslek bilgisi dediğimiz pedagojik formasyon derslerinin daha baskın hâle geldiği söylenebilir.

2018 yılındaki Sosyal Bilgiler Öğretmenliği Lisans Programı'nın 1998 ve 2006 Programı'ndan ayrılan önemli bir özelliği ise öğretmenlik uygulamasının iki döneme çıkarılmasıdır. Okul Deneyimi dersi kaldırılmış ve yerine Öğretmenlik Uygulaması dersi konulmuştur. Öğretmen adaylarının öğretmenlik uygulamasına ilişkin çeşitli sorunlarla karşılaşmalarına rağmen Öğretmenlik Uygulaması dersinden memnun kaldıkları, özellikle öğrenilen kuramsal bilgileri uygulamaya geçirme ve sınıf yönetimi konusunda tecrübe kazandıkları sonucuna (Beldağ \& Yaylac1, 2014) binaen Öğretmenlik Uygulaması dersinin iki döneme çıkarılmış olması olumlu bir gelişme olarak değerlendirilmektedir.

Bunlarla beraber daha önce çeşitli üniversitelerde seçmeli ders olarak okutulan ve sosyal bilgiler eğitimin daha özel alanını oluşturan Karakter ve Değer Eğitimi, Afetler ve Afet Yönetimi, Medya Okur Yazarlığı ve Eğitimi, Eğitimde Ahlak ve Etik gibi derslerin 2018 Programı'nda ana dersler içinde olduğu görülmektedir. Bu durum sosyal bilgilerin amaçlarının gerçekleşebilmesi açısından olumlu değerlendirilmektedir.

Program geliştirme, uzun bir süreci kapsayan, geri bildirimlere dayanan ve ihtiyaca dayalı olarak değişimi ortaya koyan bir süreçtir. $\mathrm{Bu}$ süreçte paydaşların yeterince haberdar edilmesi, program geliştirmenin gerekçelerinin bilimsel çalışmalara dayanılarak detaylı olarak belirtilmesi araştırmacılarda ve sosyal bilgiler eğitimcilerinde oluşacak soru işaretlerini ortadan kaldıracaktır. Bunlarla beraber öğretmenlik artık geçtĭgimiz yüzyıldan farklı olarak, uygulamaya daha çok ağırlık veren bir meslek hâline gelmiştir. Buna rağmen sosyal bilgiler öğretmenliği lisans programlarında uygulamanın artacağı yere giderek azalmasının gerekçeleri belirsizliğini korumaktadır. Ayrıca "uygulama" denildiğinde ne anlaşılabileceği de detayları ile programlarda yer almalıdır.

Sosyal bilgiler öğretmenliği lisans programında 20 y1l içinde olumlu veya olumsuz değerlendirilebilecek bazı gelişmeler yaşamıştır. Ancak çeyrek yüzyıl içinde öğretmen adaylarına entelektüel anlamda bilgi yüklemek misyonu değişmemiştir. Bu bağlamda öğretmenler ve akademisyenler olarak düşünmemiz gereken ise bu şekilde mezun olan sosyal bilgiler ögretmen adaylarının etkili vatandaş yetiştirmeye istenilen katkıyı sağlayıp sağlayamayacaklarıdır. 


\section{KAYNAKÇA}

Akbaba, B. \& Aksoy, B. (2019). Sosyal bilgilerde beceri eğitimi. B. Aksoy, B. Akbaba \& B. Kılcan (Ed.), Sosyal bilgilerde beceri eğitimi içinde (s. IX-XVII). Pegem Akademi.

Akhan, N. E. (2015). Sosyal bilgiler öğretmen adaylarının sosyal bilgiler lisans programı üzerine düşünceleri. International Journal of Social Science, 32(3), 267-289, http://dx.doi.org/10.9761/JASSS2735

Aslan. E. (2016). Geçmişten günümüze sosyal bilgiler. D. Dilek (Ed.), Sosyal bilgiler eğitimi içinde (s. 3-52) Pegem Akademi.

Aymankuy, Y. \& Ceylan, U. (2013). Ailelerin turistik ürün satın alma karar sürecinde çocukların rolü (yerli turistler üzerinde bir araştırma). Elektronik Sosyal Bilimler Dergisi, 12(45), 105-122. https://dergipark.org.tr/tr/download/article-file/70462

Beldağ, A. \& Yaylacı, A. F. (2014). Sosyal bilgiler öğretmen adaylarının eğitim sistemi hakkındaki görüşleri. Elektronik Sosyal Bilimler Dergisi, 13(48), 90-107. https://dergipark.org.tr/en/download/articlefile/70525

Çulha Özbaş, B. (2012). Sosyal bilgiler öğretmeni olarak, ben kimim? Sosyal bilgiler öğretmenlerinin mesleki kimliklerine yönelik görüşlerinin metafor analizi yoluyla incelenmesi. Turkish Studies-International Periodical For The Languages, Literature and History of Turkish or Turkic, 7(2), 821-838.

Demircioğlu, İ. H. (2006). Sosyal bilgiler öğretmen adaylarının sosyal bilimler hakkındaki görüşleri. Bilig, 36, 113-124. https://app.trdizin.gov.tr/publication/paper/detail/TnpFM05qYzM

Doğanay, A. (2008). Çağdaş sosyal bilgiler anlayışı ışığında yeni sosyal bilgiler programının değerlendirilmesi. Ç.Ü. Sosyal Bilimler Enstitüsü Dergisi, 17(2), 77-96. https://dergipark.org.tr/en/download/articlefile/50439

Evans, R. (2004). The social studies wars: What should we teach the children? Teachers College Press.

İnan, S. (2014). Sosyal bilgiler eğitimi: Nedir, ne zaman ve neden. S. İnan (Ed.), Sosyal bilgiler eğitimine giriş içinde (s. 1-21). Anı Yayıncılık.

Gülerarslan, A. (2011). Tüketici olarak çocuk ve ailenin satın alma kararlarına etkisi. Selçuk İletişim, 6, 126-137 https://doi.org:10.18094/SI.34727

Kabapınar, Y. (2014). Kuramdan uygulamaya sosyal bilgiler öğretimi. Pegem Akademi Yayınları.

Karasu Avcı, E. (2017). Sosyal bilgiler öğretmen adaylarının sosyal bilgiler öğretmenliği lisans programı ile ilgili görüşleri. International Journal of Eurasia Social Sciences. 8(27), 756-786. http://www.ijoess.com/Makaleler/760888485_18.\%20756-786emine\%20avc\%c4\%b1.pdf

Kaya, E. \& Bursa, S. (2018). Öğretmen adaylarının sosyal bilgiler dersinin yapısı ve toplu öğretim sistemine ilişkin farkındalıkları. Route Educational and Social Science Journal, 5(11), 1-24. http://dx.doi.org/10.17121/ressjournal.1500

Kaymakcı, S. (2012). Sosyal bilgiler öğretmenliği lisans programlarının içerik değerlendirmesi. UluslararastSosyal Bilimler Eğitimi Dergisi, 2(1), 45-61. https://dergipark.org.tr/en/download/article-file/261761

Kaymakcı, S. \& Ata, B. (2012). Sosyal bilgiler öğretmenlerinin sosyal bilgilerin doğasıyla ilgili görüşleri. Sosyal Bilgiler Eğitimi Araştırmaları Dergisi. 3(1), 35-64. https://dergipark.org.tr/en/download/articlefile/179031

Kaymakcı, S. \& Akbaba, B. (2014). Sosyal bilgiler öğretmen adaylarının geçmiş yaşantılarında öğrenemedikleri konular ve bunlara ilişkin çözüm önerileri. Türkiye Sosyal Araştırmalar Dergisi, 18(3), 145-165. https://dergipark.org.tr/tr/download/article-file/200588

MEB. (2005). İlkögretim sosyal bilgiler dersi 6-7. siniflar ögretim programı ve kılavuzu. Devlet Kitapları Müdürlüğ̆̈.

Özav, L. (2001). Sosyal bilgiler öğretmenliği lisans programı üzerine düşünceler. Afyon Kocatepe Üniversitesi Sosyal Bilimler Dergisi, 3(1), 165-177. https://sbd.aku.edu.tr/III1/14.pdf

Sağdıç, M. (2018). Türkiye'de 2018 yılında uygulamaya konulan sosyal bilgiler lisans programının 2006 lisans programı ile karşılaştırılması. Uluslararası Sosyal ve Eğitim Bilimleri Dergisi, 5(10), 308-321. https://doi.org/10.20860/ijoses.488657

Şahin, M. \& Güvercin Çetinoğlu, A. (2006). Sosyal bilgiler öğretmen adaylarının bölümlerindeki ders ve uygulamalara iliş̧in algıları. e-Uluslararası Eğitim Araştırmaları Dergisi. 7(1), 50-69. http://static.dergipark.org.tr/article-download/f7b7/4480/a103/imp-284720-0.pdf

Tay, B. (2011). Sosyal bilgiler öğretiminin dünü bugünü ve yarını. R. Turan \& K. Ulusoy (Ed.), Sosyal bilgilerin temelleri içinde (s. 2-17). Pegem Akademi.

Tonga, D. (2012). Sosyal bilgiler öğretmenliği lisans programının değerlendirilmesi. Türk Eğitim Bilimleri Dergisi, 10(4), 779-803. https://dergipark.org.tr/tr/download/article-file/256174

Tonga, D. (2013). 8. Sinıf öğrencilerinin vatandaşlık bilinci düzeylerinin çeşitli değiş̧kenler açısından değerlendirilmesi [Yayımlanmamış Doktora Tezi]. Gazi Üniversitesi. 
Tonga, D. (2016). What do teacher candidates think about the teaching education? The example of social studies teacher candidates. Zeitschrift für die Welt der Türken Journal of World of Turks, 8(3), 217-234. http://www.dieweltdertuerken.org/index.php/ZfWT/article/view/892/892

Ünlü, İ., Koçoğlu, E. \& Ay, A. (2015). Sosyal bilgiler lisans programındaki uygulamalı derslere yönelik öğretmen adayı görüşlerinin incelenmesi. Mediterranean Journal of Humanities, 1, 371-386. https://doi.org/10.13114/MJH.2015111389

Yıldırım, A. (1999). Nitel araştırma yöntemlerinin temel özellikleri ve eğitim araştırmalarındaki yeri ve önemi. Ĕgitim ve Bilim, 23(112), 7-17. http://egitimvebilim.ted.org.tr/index.php/EB/article/view/5326/1485

Yıldırım, A. \& Şimşek, H. (2008). Nitel araştırma yöntemleri. Seçkin Yayıncılık.

Yılmaz, K. \& Tepebaş, F. (2011). İlköğretim düzeyinde sosyal bilgiler eğitiminde karşılaşılan sorunlar: Mesleğine yeni başlayan sosyal bilgiler öğretmenlerinin görüşleri. Çankırı Karatekin Üniversitesi Sosyal Bilimler Enstitüsü Dergisi, 2(1), 157- 177. https://dergipark.org.tr/tr/download/articlefile/254066

Yılmaz, K. (2009). Lisans düzeyinde sosyal bilgiler eğitiminde karşılaşılan sorunlar ve çözüm önerileri: Öğretmen adaylarının görüşleri. Ondokuz Mayıs Üniversitesi Eğitim Fakültesi Dergisi, 27, 31-53. https://dergipark.org.tr/tr/download/article-file/188059

YÖK. (1998). Eğitim fakültesi öğretmen yetiştirme lisans programlart. http://www.yok.gov.tr/documents/10279/30217/Egitim_fakultesi_ogretmen_yetistirme_lisans_progra mlari_mart_98.pdf/5e166018-b806-48d5-ae13-6afd5dac511c

YÖK. (2007). Eğitim fakültesi öğretmen yetiştirme lisans programlart. http://www.yok.gov.tr/documents/10279/30217/E\%C4\%9E\%C4\%B0T\%C4\%B0M+FAK\%C3\%9CL TES\%C4\%B0\%20\%C3\%96\%C4\%9ERETMEN+YET\%C4\%B0\%C5\%9ET\%C4\%B0RME+L\%C4\% B0SANS+PROGRAMLARI.pdf/054dfc9e-a753-42e6-a8ad-674180d6e382

YÖK. (2018). Eğitim fakültesi ögrretmen yetiştirme lisans programları. Ankara Üniversitesi Basımevi Müdürlüğ̈̈ 


\section{EXTENDED ABSTRACT}

\section{Introduction}

Social studies education curricula and social studies teaching programs update work has been carried out one after the other. As a result of the new social studies course, which started to be taught in Turkey in 2005, a new social studies teaching undergraduate program put into practice in 2006. Also in 2018, the new social studies teaching undergraduate program was in effect immediately after the change of social studies curriculum in 2017.

When we look at the literature, studies on social studies undergraduate education include the opinions of prospective teachers on social studies teaching undergraduate program, studies aiming to evaluate social studies teaching undergraduate programs, and studies comparing social studies teaching undergraduate programs in different years. However, there are no studies evaluating the educational programs of 1998, 2006 and 2018 social studies teaching programs and comparing them in various aspects. Therefore, with this study, it is aimed to shed light on the last twenty years of social studies teaching, and to fill a gap that is believed to exist in the literature. In this context, it is aimed to reveal the changes in the undergraduate social studies teaching program from the beginning to the present.

\section{Method}

This study was designed in accordance with the qualitative research approach, as the answer to the question of "How is the change in the social studies teaching program over the last 20 years?" was sought. As a data collection tool, document review which is believed to be the most effective way of collecting data about the problem sentence, was used. Document review covers the analysis of written documents containing information about the cases or facts intended to be investigated. The examined documents were limited to the undergraduate programs of social studies teaching in 1998, 2006 and 2018 and only the documents of the Higher Education Council were taken as the basis. Some of the documents related to the programs were obtained from the official website of the Council of Higher Education and some of them from the printed works of the Higher Education Council.

Descriptive analysis is given on the obtained data. The data obtained in the descriptive analysis are summarized and interpreted according to the predetermined themes.

\section{Findings, Discussion and Results}

When the undergraduate programs of Social Studies Education are evaluated in general, the 1998 program with Turkish side courses, the 2006 program with the social science disciplines forming the social studies and the 2018 program with the majority of the courses under the title of professional knowledge draws attention. As of the last point where the social studies teaching undergraduate program comes, it is determined that the number of practical courses is reduced, and the social sciences discipline, which is the scope of social studies, is removed from the main courses and that the concept of "Education" is added to the beginning or the end of the courses.

In terms of the total number of courses, 57 courses in the 1998 program increased to 61 in 2006 and 68 in the 2018 program. On the other hand, in the context of the teacher education program, the hours of social studies teachers were 163 hours in the 1998 program, increased to 170 hours in the 2006 program and then decreased to 154 hours in 2018 program. As for the last point, it is observed that, the courses increased and the course hours decreased.

The practical courses which were 32 hours in the 1998 program decreased to 28 hours in the 2006 program and 14 hours in the 2018 program. On the other hand, theoretical courses of 131 hours in the 1998 program increased to 140 hours in the 2018 program. When these two results are considered together, it is seen that the practice is ignored in teaching education and instead, it is given as much theoretical lecture as it can be given. In many studies in literature, there are contradictory results. For example, in the studies conducted with pre-service teachers, pre-service teachers stated that they expected more practice from social studies teaching program, and they could not benefit adequately from the theoretical courses because they did not have enough practice. There are many studies stating that social studies teachers did not know how to use the information when they started teaching because the information was not beyond memorization.

In terms of elective courses, there were only 3 elective courses in the 1998 program, which increased to 7 in the 2006 program and 16 in the 2018 program.

When the social sciences teaching in social sciences are evaluated in terms of how they are included in the undergraduate programs, there are 8 social science disciplines: History, Geography, Citizenship, Psychology, 
Economics, Archaeology and Philosophy. These courses include 22 hours of history lessons and 20 hours of geography lessons. In 2006, 11 social science disciplines including History, Geography, Citizenship, Sociology, Social Psychology, Economics, Law, Archaeology, Philosophy, Anthropology and Political Science are included. Among these, history lessons are 24 hours and geography lessons are 16 hours. In 2018, five social science disciplines, namely History, Geography, Citizenship, Anthropology and Political Science, are included. The history courses are 18 hours and geography courses are 12 hours. In the last point, while the weight of history and geography courses are reduced in social studies teaching program, it is seen that many disciplines related to social sciences are taken from the main courses and placed as elective courses. However, in the studies conducted with social studies teacher candidates in the literature did not know how to relate between disciplines.

In the 2018 program, the names and contents of some courses have changed. It is seen that the concept of "Education" is added to the beginning or the end of the names of the courses. For example, the course of Sociology changed to Sociology of Education, the course of Philosophy changed to Education Philosophy, Human Rights and Democracy course to Human Rights and Democracy Education. The name of the Introduction to Education Science course has changed and it has become an Introduction to Education. The course, which was previously as Measurement and Evaluation, has changed as Measurement and Evaluation in Education.

The social studies teaching undergraduate program has experienced some positive or negative evaluations in 20 years. However, it has not changed its mission to load knowledge in the intellectual sense within a quarter of a century. In this context, it is seen that there is not sufficient progress to gain the values and skills of prospective teachers. However, teaching is a profession of value and skill. In the university entrance exams, pre-service teachers are already placed in departments with multiple choice tests. Teacher candidates are not given value and skills training in undergraduate education. In this manner, what we must think of as teachers and academics is that how these social studies teacher candidates will contribute to the development of effective citizens and whether effective citizenship is merely information. 


\section{ETIKK BEYANNAME}

$\mathrm{Bu}$ çalışmanın araştırma ve yazım sürecinde araştırmacı / araştırmacılar tarafından bilimsel ve etik kurallara uyulduğunu, farklı eserlerden yararlanılması durumunda atıfta bulunulduğunu, kullanılan verilerde herhangi bir tahrifat yapılmadığını, araştırmanın tamamının veya bir kısmının farklı bir akademik yayın platformuna yayımlanmak üzere gönderilmediğini, belirtilen konularda araştırmanın yazarının / yazarlarının bilgi sahibi olduğunu ve gerekli kurallara uyulduğunu beyan ederim. 04/09/2020

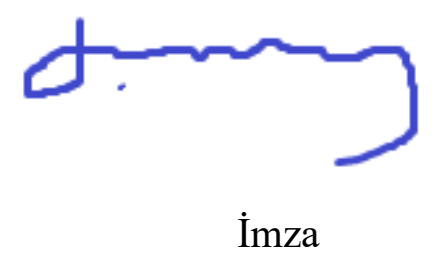

Ad1 Soyad1

Araştırmanın Sorumlu Yazarı

Deniz TONGA 